\author{
UNIVERSIDADE DE SÃO PAULO \\ INSTITUTO DE MATEMÁTICA E ESTATÍSTICA \\ MESTRADO PROFISSIONAL EM ENSINO DE MATEMÁTICA
}

\title{
O ENSINO DE MATEMÁTICA E AS LINGUAGENS: \\ LOGARITMOS COMO EXPOENTES
}

Dissertação apresentada ao Programa de Mestrado Professional em Ensino de Matemática do Insituto de Matemática e Estatística da Universidade de São Paulo para obtenção do título de Mestre em Ciências

Orientador: Prof. Dr. Ricardo Bianconi

São Paulo 


\author{
UNIVERSIDADE DE SÃO PAULO \\ INSTITUTO DE MATEMÁTICA E ESTATÍSTICA \\ MESTRADO PROFISSIONAL EM ENSINO DE MATEMÁTICA
}

\title{
O ENSINO DE MATEMÁTICA E AS LINGUAGENS: \\ LOGARITMOS COMO EXPOENTES
}

DANIEL TAKAHASHI DEMETRIO DE AQUINO

São Paulo 
Agradecimentos

Muito Obrigado. 


\section{Vício na fala}

Para dizerem milho dizem mio

Para melhor dizem mió

Para pior pió

Para telha dizem teia

Para telhado dizem teiado

E vão fazendo telhados

Oswald de Andrade 
Aquino, DTD. O ensino de Matemática e as linguagens: Logaritmo como expoente [tese]. São Paulo: Instituto de Matemática e Estatística, Universidade de São Paulo; 2018.

\section{RESUMO}

Introdução: Os Logaritmos, objeto matemático desenvolvido há quatro séculos como uma ferramenta facilitadora de cálculos hoje gozam de uma miríade de outros significados, mas manteve seu signo, sua maneira de representação, estagnado no tempo. A Língua Materna e a Matemática estão entrelaçadas e impregnam uma à outra. Como a Língua Materna é a principal influência na formação do raciocínio, esta enraíza-se e permeia as aulas e o ensino de todas as disciplinas, incluindo as de Matemática. Objetivo: Este trabalho visa propor uma modernização para a notação matemática e modo de se interpretar os logaritmos para uma forma mais concordante com a organização de pensamento dos falantes de Língua Portuguesa do Brasil, haja visto que a leitura e maneira de representar um objeto matemático estão diretamente ligadas com o processo de aprendizagem de um indivíduo. Método: Delineada como pesquisa explicativa de abordagem qualitativa, o estudo utilizou de textos e ideias da Linguística, Educação e Matemática para explicitar os efeitos da notação de representação de um objeto matemático no ensino e aprendizagem, e propor maneiras de como utilizar estes efeitos de maneira positiva para a transposição didática do conhecimento. Conclusões: A maneira como a Língua Materna embasa o raciocínio de seus falantes é um fator importante a se considerar na elaboração de uma notação de representação em Matemática. Como as diferentes representações de um objeto estão diretamente ligadas com a aprendizagem, torna-se essencial buscar uma maior concordância entre a representação, impregnada tanto de Matemática quanto de Língua Materna, e o representado, o conhecimento matemático em questão.

PALAVRAS-CHAVE: Logaritmos. Sistemas de representação. Transposição didática. Notação Matemática. 
Aquino, DTD. Mathmatical teaching and languages: Logarithm as an exponent [thesis]. São Paulo: Insituto de Matemática e Estatística, Universidade de São Paulo; 2018.

\begin{abstract}
Introduction: The Logarithms, the mathmatical object developed four centuries ago as a tool to facilitate calculations today possesses a myriad of other meanings, but kept its sign, its representation, stagnant in time. The Mother Language and the Mathmatics are entangled and impregnate one another. Since the Mother Language is the main influence in the development of the reasoning, it permeates classes and teaching of all subjects, including the Mathmatical ones. Goal: This paper aims to propose an update to the mathmatical notation and way of rendering the logarithms to a more concordant form with the though organization of the Portuguese speakers of Brazil, since the signs and representation of a mathmatical object are directly connected with the learning process of an individual. Method: Outlined as an qualitative approach and explanatory research, the paper used texts and ideas from Linguistics, Education and Mathmatics to explicit the effects of notation and the representations of a mathmatical object in the learning process while also proposing ways to use this effects in a positive manner to the didactic transposition of the knowledge. Conclusions: The way the Mother Language bases the thought organization is an important factor to consider in the elaboration of a mathmatical notation and representation in Mathmatics. Since a multitude of representations are directly connected with the learning process, its essential to search for a concordance between the representation, impregnated both with Mother Language and Mathmatics, and the represented, the mathmatical object.
\end{abstract}

KEYWORDS: Logarithms. System of representation. Didactic transposition. Mahmatical notation. 


\section{LISTA DE ILUSTRAÇÕES}

Figura 1 - Processamento de uma sentença em outra língua

Figura $2-(a+b)^{2}$

Figura 3 - O logaritmo

Figura 4 - Proposições para a notação (escrita)

Figura 5 - Ordem na notação atual

Figura 6 - Proposições para a notação (posição) 


\section{SUMÁRIO}

INTRODUÇÃO

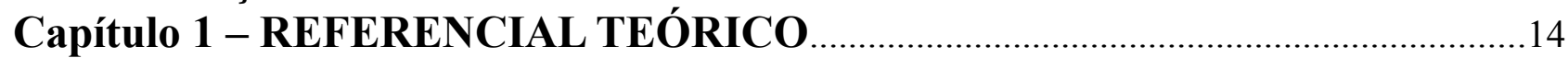

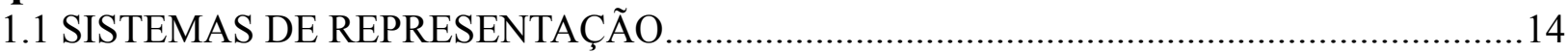

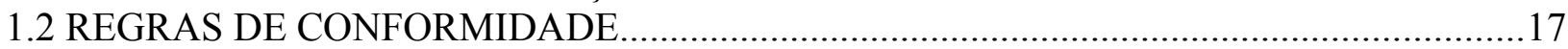

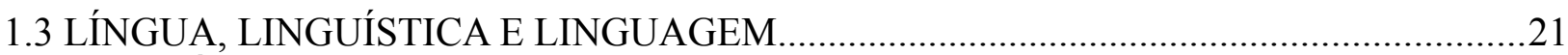

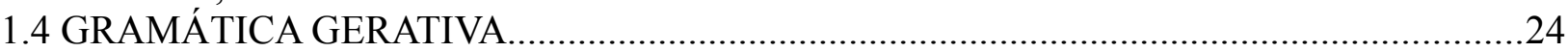

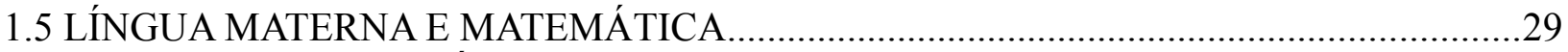

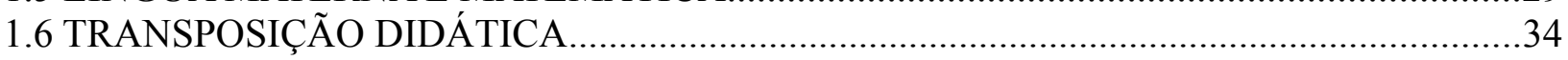

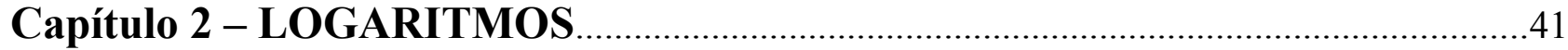

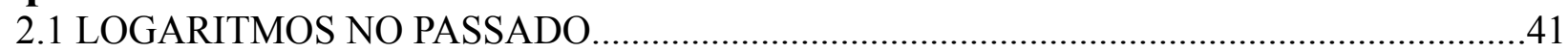

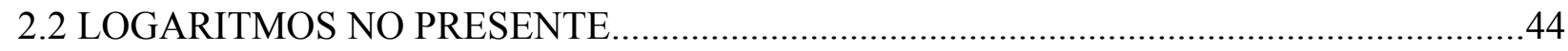

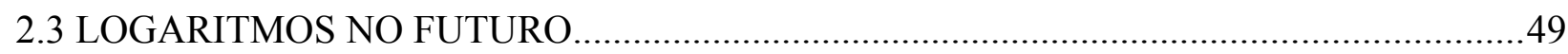

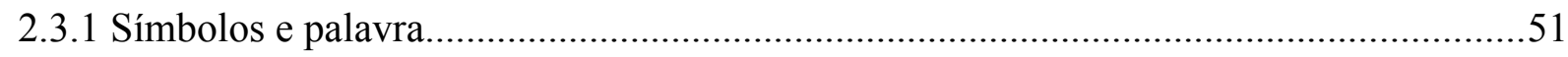

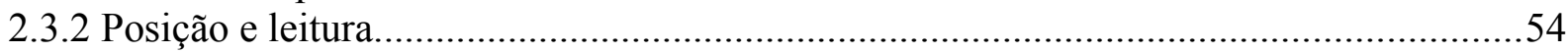

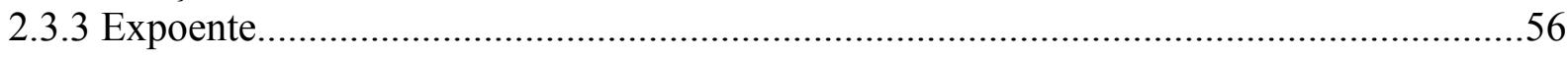

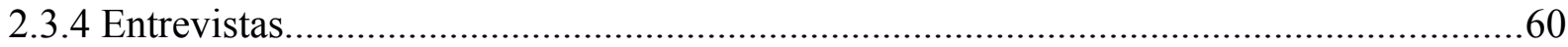

CONCLUSÃO

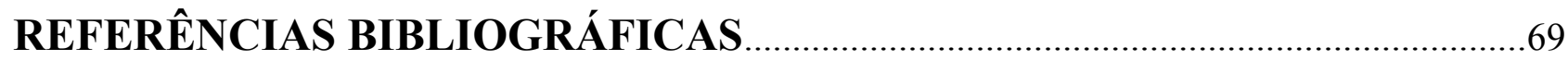




\section{INTRODUÇÃO}

$\mathrm{Na}$ antiguidade, mais especificamente entre a Grécia antiga e a Idade Média, era trivial saber argumentar para o bom convívio político. Etimologicamente falando temos que a palavra trivial vem da palavra em latim trivium, que significava a união de três disciplinas fundamentais da educação naquela época: a Lógica, a Gramática e a Retórica, consideradas o currículo básico para a formação do cidadão. Grosso modo, um indivíduo que tivesse conhecimento da língua, suas palavras escritas e orais, e a organização das mesmas em frases coesas e coerentes (gramática), soubesse montar suas frases de forma persuasiva, para melhor atingir seus ouvintes (retórica) e tudo isso de maneira bem argumentada, evitando duplos sentidos e com um texto dialeticamente correto (lógica), ou seja, um indivíduo capaz de dominar o trivium, era um cidadão trivial, não fazendo mais que o mínimo para conviver de forma política e em sociedade.

Devemos tomar cuidado, entretanto, pois esta união não é puramente linear, não podemos dizer que bastam coexistir as três disciplinas e admitir que a partir de tal ponto tudo será coerente e coeso, persuasivo e bem argumentado. Enquanto a Gramática e a Retórica estão cuidando de um bom vocabulário e da persuasão do interlocutor por parte do locutor, a Lógica por sua vez busca relacionar os elementos do discurso e das frases de modo a garantir a boa argumentação, mas por ser uma linguagem formal, se preocupa inicialmente com a forma e não com o conteúdo. Uma sentença como "Se os elefantes voam, então os jaguares também" é logicamente correta, mas utiliza duas premissas falsas e possui pouco valor num discurso persuasivo. É importante considerar que

\footnotetext{
[...] nas situações da vida cotidiana, diferentemente dos contextos da Lógica Formal, para argumentar é fundamental interessar-se pela verdade das premissas, tanto quanto o é explicitar os nexos entre elas e a conclusão que se apresenta como verdadeira. E como o que se busca, em geral, é convencer os outros e persuadi-los a agir do modo que nos interessa, muitos recursos extralógicos, dispensáveis numa perspectiva puramente formal, são utilizados pelos participantes de um debate, de uma discussão, de uma argumentação. (MACHADO 2008, Pg. 51)
}

Mostrando que para a elaboração de um bom discurso, é de suma importância tanto a forma da argumentação, sua validação e coesão, quanto a validade da informação tratada, pois um discurso convincente nunca poderá se basear em falácias ou argumentações pobres, mal explicadas. Esta boa argumentação se dá tanto na dimensão da Gramática quanto nas da 
Retórica e da Lógica.

A Língua Materna e a Matemática, segundo Nílson José Machado, estão impregnadas uma da outra, complementam-se e caminham lado a lado, afirma também que:

[...] tomar consciência das inúmeras nuances da linguagem natural pode nos ajudar a identificar argumentos falhos ou tendenciosos, a evitar equívocos ou mal entendidos, mas nunca reduzirá a comunicação humana aos limites de uma linguagem de programação de computadores. Mesmo em tais linguagens, em tempos recentes, a ocorrência cada vez mais frequente de 'vírus', que se encaixam em brechas de procedimentos estritamente lógicos e remetem a operações não prefiguradas pelo programador original, parece um indício enfático da impossibilidade de uma perfeita algoritmização da própria linguagem de programação (MACHADO; CUNHA, 2008, P. 84).

Ao tratar a Língua Materna ao lado da Matemática, não estamos tentando construir uma ciência em forma de amálgama das duas, mas sim evidenciar em que esta impregnação mútua proposta por Machado tem a oferecer para a Educação Matemática, que segundo as palavras de Santos e Lins (2016)

é uma atividade que se constitui em diversos e diferentes diálogos com a Filosofia, Antropologia, Sociologia, História, Psicologia, como também com qualquer outra área do conhecimento com a qual educadores matemáticos possam e queiram dialogar.

Esta impregnação se dá em cada representação da matemática, uma abrangência muito maior do que um único trabalho poderia conter, portanto o ponto em que focamos nossos estudos é o objeto matemático dos logaritmos, sua notação escrita e representação. Ao analisar sua estrutura sintática, os signos que utilizamos para representá-lo e a maneira como se concatenam estes símbolos em meio a uma sentença matemática, estamos buscando a maneira como a impregnação da Matemática pela Língua Materna se dá neste objeto matemático, como isto afeta a maneira como o representamos e por consequência apreendemos este conhecimento na forma de um saber.

Por experiências próprias, os logaritmos são considerados um estigma na Matemática, um ponto sensível que nem sempre consegue ser significativo para o estudante. Portanto também acreditamos ser necessário entender a origem e significado dos logaritmos através da história, desde sua concepção como objeto matemático até seus usos atuais. Esta análise histórica unida da maneira como a transposição didática do conhecimento científico até o saber ensinado oferecem um ponto de vista abrangente para que possamos tentar justificar 
nossas crenças de que os logaritmos são parte importante do conhecimento matemático e não devem ser vistos com préconceitos.

Nosso interesse por esse tema vem da consciência de que a Matemática não é um conhecimento escrito em tábulas sagradas de pedra, onde não se constrói mas só se reproduz o já feito pelos gregos da antiguidade. Esta visão exagerada e errônea muitas vezes é compartilhada por jovens e adultos que desconhecem sequer parte da abrangência verdadeira da Matemática: muito além dos números e contas, esta ciência que estuda as relações entre os objetos está em desenvolvimento contínuo e definitivamente não estagnar-se-á.

Já que a Matemática cresce, acreditamos ser justificável rever as representações dos objetos matemáticos utilizadas cotidianamente e a validez do estudo destes objetos em questão.

Para enfrentar o problema proposto, iremos na primeira parte deste trabalho definir como consideraremos a transmissão do conhecimento científico para o saber de um indivíduo, como este saber se relaciona com o conhecimento e o representa e a que regras está sujeita esta representação para que ela seja significativa para uma comunidade. Consideraremos também pontos de vista e argumentos da ciência que estuda as relações sintáticas entre símbolos, a Gramática Gerativa de Noam Chomsky, e analisaremos a linguagem da Matemática ao lado da linguagem da Língua Materna que, segundo Machado, impregnam-se uma da outra e se complementam. Veremos como podemos considerar estas múltiplas maneiras de se representar um objeto matemático como diferentes representações semióticas e porque estas são essenciais para que se ocorra uma aprendizagem significativa.

$\mathrm{Na}$ segunda parte do trabalho, realizaremos uma análise histórica do caminho percorrido pelos logaritmos, desde sua primeira definição e usos até a modernidade, quais as similaridades e diferenças entre a maneira de se enxergar este objeto matemático ao passar dos anos e quais significados podem e são atribuídos a ele. Como diz Machado:

Até os dias atuais, decorridos quase quatro séculos, os logaritmos ainda são ensinados na escola. No entanto, o professor que pretender justificar o seu estudo tendo em vista as simplificações nos cálculos, não corre o risco de ser desacreditado pelos alunos: sê-lo-á com toda a certeza. A crescente utilização de máquinas calculadoras relativizou em demasia o significado prático da facilitação de cálculos, e insistir nesse ponto parece inteiramente extemporâneo. É possível argumentar sobre a continuidade do seu ensino, em função da necessidade de compreensão dos processos de cálculo, para possibilitar uma postura crítica diante das realizações das máquinas. Apesar de pertinente, tal argumentação, no entanto, é absolutamente secundária, diante do seguinte fato: hoje há novas e importantes aplicações dos logaritmos, substancialmente 
distintas daquelas que motivaram o seu estudo originalmente. (MACHADO, 2011, p. 78-79)

Em seguida proporemos uma maneira alternativa, e o porque acreditamos ser mais significativa, de representar os logaritmos: como expoentes. Explicitaremos o processo de elaboração desta nova forma de representação, justificando cada particularidade da mesma com a teoria apresentada na parte um do trabalho e então seguiremos com uma série de análises de entrevistas que foram realizadas como validação de tudo que será proposto até então.

Acreditamos que não somente é necessário se preocupar com o objeto de ensino e a maneira de se ensinar mas também com a maneira de representar este objeto, representação esta que deve ser significativa para os falantes de uma determinada Língua, pois a Língua Materna se mostra uma das principais construtoras do raciocínio de um indivíduo de modo que falantes de diferentes línguas possuem diferentes maneiras de enxergar o mundo ao seu redor. 


\section{Capítulo 1 - REFERENCIAL TEÓRICO}

Apresentaremos, neste primeiro capítulo, alguns autores e pensamentos que contribuíram na elaboração desta pesquisa. As ideias a seguir serão de suma importância para o restante do trabalho, desde explicitar a maneira como trataremos a apreensão de conhecimento por parte de um estudante até como se dá a transposição deste conhecimento construído por uma comunidade científica até o saber de um indivíduo. Também é necessário se atentar ao modo como a Língua Materna e a Matemática impregnam uma à outra e quais as influências desta impregnação no ensino de Matemática.

\subsection{SISTEMAS DE REPRESENTAÇÃO}

Quando um aluno se depara com um novo raciocínio, conteúdo ou objeto matemático, e inicia-se o processo de aprendizagem, este é dado através de representações do objeto, como o gráfico de uma reta no plano cartesiano, sua equação reduzida ou a frase "reta que passa nos pontos A e B"; todas essas representações se referem ao mesmo objeto: a reta AB. Esta ideia é similar a Teoria das ideias de Platão, onde não era possível alcançar a ideia, substância perfeita, imutável e abstrata, qualquer que ela fosse, mas sim apenas interagir com os objetos materiais que apenas se apropriam de parte da essência abstrata, com mais imperfeições e nunca contemplam o objeto em sua totalidade.

A Teoria dos registros de representação semiótica é parte dos estudos de Raymond Duval, psicólogo e filósofo francês nascido em 1937, em que ele se baseia em trabalhos anteriores de Charles Sanders Perice e Ferdinand de Saussure sobre semiótica (MORETTI e THIEL, 2012, p. 379 - 396). Segundo Regina Flemming Damm, Duval chama de semiose a apreensão ou produção de uma representação semiótica e a noese de apreensão conceitual de um objeto, sendo que uma representação semiótica, geralmente, é considerada um suporte para uma representação mental, aquelas que são feitas internamente a um indivíduo para si mesmo, e as representações semióticas possuem o fim de comunicar estas representações mentais aos demais. Duval também afirma que este ponto de vista é ingênuo pois as representações semióticas não possuem somente o fim de comunicação, mas também são igualmente essenciais para as atividades cognitivas do pensamento. (MACHADO 2010, p. 
Resumidamente, podemos entender que um indivíduo cria representações mentais para o mundo ao seu redor, em busca de melhor compreendê-lo. Devido às diferenças funcionais do modus operandi de cada um, estas representações mentais são concebidas e manipuladas de modos ímpares para cada individuo. Quando se torna necessário expor esta visão internalizada, a representação mental precisa ser traduzida em uma representação semiótica, que possua suas próprias regras e símbolos, estipulados em comunidade, para melhor compreensão do que é representado, uma notação matemática, uma ordem de concatenação de palavras como "eu tomo café" ser correta e "tomo café eu" não ser, são exemplos destas regras e símbolos estipulados pela comunidade. Todo o processo de apreensão conceitual do representado (noesis) não é possível sem uma produção de uma multiplicidade de representações semióticas diferentes (semiosis). Segundo Duval (2009, p. 38)

\begin{abstract}
uma representação pode verdadeiramente funcionar como representação, quer dizer, dar-lhes acesso ao objeto representado apenas quando duas condições são preenchidas: que eles disponham de ao menos dois sistemas semióticos diferentes para produzir a representação de um objeto, de uma situação, de um processo... e que eles possam converter "espontaneamente" de um sistema semiótico a outro, mesmo sem perceber as representações produzidas. Quando essas duas condições não são preenchidas, a representação e o objeto representado são confundidos, e duas representações diferentes de um mesmo objeto não podem ser reconhecidas como sendo as representações do mesmo objeto.
\end{abstract}

Ou seja, é necessário para o verdadeiro aprendizado que o aluno saiba tanto reconhecer e manipular diferentes representações de um mesmo objeto quanto transitar entre elas, observando este objeto matemático como que por múltiplos ângulos, de modo a melhor vislumbrar sua totalidade. Se este indivíduo só possuir um único ponto de vista sobre um objeto, ele é confundirá esta única visão do objeto com o próprio, e esta falsa ideia de compreensão da totalidade do objeto é danosa para a verdadeira compreensão do conceito, situação ou procedimento estudado. A tradução de uma representação semiótica em outra é uma atividade indispensável para a verdadeira apreensão conceitual, não sendo menos importante que a própria produção das representações, pois é transformando uma representação em outra que se torna possível associar um mesmo objeto a múltiplos pontos de vista, podendo-se então contemplá-lo de uma maneira mais completa e compreendê-lo de uma maneira mais satisfatória.

É de suma importância também ressaltar que nenhuma representação de um objeto pode conter o mesmo em sua totalidade, caso pudesse ela deixaria de ser uma representação e passaria a ser o próprio objeto. Continuando com o exemplo do parágrafo inicial desta seção, 
quando se representa a reta $\mathrm{AB}$ por seu gráfico temos em nossa frente uma série de informações a respeito do objeto representado, podemos observar sua inclinação e, dependendo de sua posição no plano, ter uma ideia de onde se situam sua raiz, mas não necessariamente sabemos sua taxa de variação, o coeficiente angular, informação que está presente na equação reduzida desta mesma reta, mas por sua vez, esta equação reduzida isolada e sem algum tipo de manipulação não nos dará uma ideia tão clara da posição da reta no plano, algo que o gráfico da reta está apto a fazer com maior clareza. Ambas as representações anteriores, por sua vez, podem não mostrar em um primeiro momento quem são os pontos $\mathrm{A}$ e $\mathrm{B}$ pertencentes à reta, que é a maior informação que a frase "reta que passa nos pontos A e B" nos traz, e esta terceira representação não contém de forma explícita outras tantas particularidades do objeto matemático que destacamos nas duas primeiras representações. Temos então que para compreender um objeto do conhecimento, no caso as retas da geometria euclidiana, é necessário conhecer múltiplas representações deste mesmo objeto, pois cada uma possui algumas informações sobre o objeto em questão e não possui outras, sendo imprescindível saber transitar livremente de uma representação para outra, para que se forme um "mapa mental" mais preciso e completo, com o menor número de lacunas possível.

Precisamos portanto saber reconhecer as informações contidas em cada uma das representações: identificar o coeficiente angular e linear da equação reduzida da reta, para que então possamos esboçar o gráfico da mesma num plano cartesiano, e substituir valores de $\mathrm{x}$ ou y na equação reduzida para podermos identificar pontos e então classificar a reta a partir de ao menos dois deles, condição que é necessária e suficiente para defini-la. Todas essas conversões e transformações, quando dominadas por um indivíduo, evidenciam um domínio sobre este assunto, de forma que o objeto "Reta" é identificável por suas várias representações, e que todas estas representações representam o mesmo objeto, mesmo que em formas tão diferentes, seja por um gráfico, seja por uma equação, seja por uma frase. Este indivíduo poderia se deparar com qualquer uma das representações e facilmente obter as outras até mesmo de maneira "espontânea", como destacado no trecho do discurso de Duval.

Apesar destas habilidades de compreensão e conversão de diferentes sistemas de representação serem indispensáveis para o desenvolvimento sadio do conhecimento para os alunos, segundo Raymond Duval (2009, p. 39)

geralmente não se distinguem as atividades, tão diferentes, de tratamento e de conversão das representações. Na descrição dos procedimentos, na dos 
andamentos ou na das estratégias de resposta, elas são reduzidas ao seu traço comum, o de transformação de representações dadas. Porém, é essencial separálas bem. Um tratamento é uma transformação que se efetua no interior de mesmo registro, aquele onde as regras de funcionamento são utilizadas; um tratamento mobiliza então apenas registros de representação. A conversão é, ao contrário, uma transformação que faz passar de um registro a outro. Ela requer então a coordenação dos registros no sujeito que a efetua.

Mostra-se clara a necessidade de expor nas aulas as ferramentas que "representam um certo objeto matemático" e as que "convertem uma representação em outra" de maneira mais explícita para que os alunos possam melhor visualizar o objeto matemático através das representações diferentes do mesmo, como que no plano platônico das ideias e somente alcançado através de visualizações parciais. Um objetivo a ser alcançado é que o aluno, ao decorrer de seus estudos, conseguir recriar mentalmente a ideia inacessível, o objeto matemático de estudo em sua forma mais completa possível.

\subsection{REGRAS DE CONFORMIDADE}

Ao se buscar a "boa escrita", pode-se num primeiro momento ser muito tentador dar um enfoque maior para as "regras gramaticais" de uma certa representação matemática, suas nuances e especificidades. Esta abordagem mais técnica já foi utilizada no passado: mesmo no século XX era comum que o ensino de geometria fosse uma releitura e reprodução de Elementos de Euclides, com uma linguagem rica em silogismos e lógica clássica. Esta abordagem se mostrou pouco eficiente pois a formalização excessiva só gerou mais dúvidas nos alunos, que viam a geometria como algo distante do mundo natural.

Segundo Duval (2009, p. 56)

As regras de conformidade permitem identificar um conjunto de elementos físicos ou de traços (sons, estados opostos de um circuito, caracteres, traços...) como sendo uma representação de qualquer coisa num sistema semiótico: seja um enunciado em alemão, seja um cálculo, seja uma fórmula de física, seja uma figura de geometria, seja uma caricatura, seja o esquema de um circuito elétrico...Elas permitem então o reconhecimento das representações como representações num registro determinado. Elas completam assim uma função de identificação de sentido para aquele que se encontra em frente de uma representação que ele mesmo não produziu. Mas isso implica que o conhecimento dessas regras seja o suficiente para a compreensão das 
representações dadas ou para sua exploração. De um ponto de vista didático e epistemológico podemos mesmo dizer que elas intervêm mais no controle de aceitabilidade de uma representação produzida, na perspectiva do registro onde ela é formada, do que na sua formação.

Ou seja, a compreensão das "regras gramaticais matemáticas", as denominadas regras de conformidade, não são pré-requisito para a "boa escrita" mas sim um subproduto da mesma. Quando um estudante se utiliza competentemente um sistema de representação, e a escrita produzida pelo aluno é aceitável para os padrões do professor numa avaliação, este geralmente conclui que o estudante domina o conhecimento. No caso da Matemática, as regras de conformidade são construídas a partir da notação utilizada. Levando isto em conta se torna essencial construir uma notação clara e de fácil uso, para que ela não seja um impecílio ao raciocínio e facilite a aprendizagem dos conhecimentos matemáticos já que esta notação é diretamente ligada a produção das representações e construções feitas pelos alunos e professores, estas por sua vez são desde uma das principais maneiras de avaliar a aprendizagem até uma parte essencial do processo da mesma, como discutido anteriormente.

Mas se não é eficiente focar explicitamente nas regras de conformidade, é menos eficiente ainda não as expor para os alunos e esperar que elas surjam espontaneamente, a liberdade total para escrever como quiser, uma ausência total de regras, com toda a certeza originaria uma enorme multitude de notações diferentes e só complicaria o processo de ensino. Torna-se então necessário guiar os estudantes para uma padronização de escrita mínima e aceitável, de modo que as representações possam ser reconhecidas e compreendidas mas não se tenha um peso e preocupação demasiados em construir essa representação, queremos que esta escrita seja o mais natural possível para o aluno para que este se concentre em resolver o problema e não em como colocar seu raciocínio de uma maneira escrita simples e eficiente. Não precisamos que cada exercício de Matemática seja resolvido em papel timbrado, mas sim que estes sejam organizados para expor o raciocínio utilizado pelo aluno, tal como é exigido numa redação, onde tanto a coesão quanto a coerência são consideradas para uma avaliação. Diferentemente da Língua Materna, esta cobrança pela "boa escrita" na Matemática pode ser feita de forma mais implícita e sutil, através da sua presença constante no discurso do professor, sua escrita e na correção de eventuais atividades dos alunos. $\mathrm{O}$ exemplo dado pelo docente possui grande influência na desenvoltura da escrita do aluno, se não a maior influência que os estudantes entrarão em contato direto. Não é certo considerar somente a linha de resultado final a uma resposta duma atividade, mas sim todo o raciocínio 
por trás do processo: um aluno que porventura erre duas passagens em seu raciocínio, trocando o sinal de positivo ou negativo de um determinado elemento da conta e obtenha o resultado final com o sinal correto ainda errou duas vezes em seu raciocínio. É necessário se atentar não somente a tais detalhes de sinal como os do exemplo mas à escrita do aluno como um todo, pois pode ser uma boa indicação da compreensão do aluno de determinado objeto matemático, sendo que a ausência de um raciocínio coeso e coerente é possível indicação de uma dificuldade em compreender o conteúdo matemático em questão.

Uma das complicações encontradas por professores e alunos de matemática é a aparente distância da linguagem lógica formal usada na construção e embasamento de conhecimentos matemáticos e da Língua Materna: ambas são encadeadas, estudadas e utilizadas de maneiras diferentes. Muito pouco se fala sobre as regras de conformidade na matemática, normalmente há uma repetição e espelhamento da notação utilizada pelo professor por parte dos alunos, que geralmente apresentam uma preocupação muito grande somente com o resultado de uma operação, não pelo caminho percorrido até este resultado. Entraremos numa discussão sobre este problema utilizando um caso mais estreito ao se trabalhar especificamente a notação utilizada nos logaritmos num capítulo posterior.

Mas serão a linguagem utilizada na Matemática e na Língua Materna tão diferentes assim? É muito comum que se tenha, ao estudar matemática, a falsa impressão de que esta é exata e escrita sobre tabuletas sagradas de pedra, imutável e completa. Este ponto de vista errôneo é comum a uma maioria da população, que muitas vezes desconhece sequer a existência de pesquisas atuais e inovadoras em Matemática. Esta suposta exatidão na Matemática é causada pelo modo como se é estudado e os conteúdos que são propostos aos alunos; desde a grande quantidade de conteúdo histórico, sejam teoremas com nomes de gregos antigos famosos, o slogan de que a Matemática é algo imutável e sempre certo, porque "dois mais dois serão sempre quatro", o que em especial não é verdade no anel $Z_{2}$, os números binários. A ideia que perdura para o cidadão comum é que a Matemática só lida com certezas. Um exemplo claro disso é que as sentenças e afirmações produzidas pela matemática do ensino básico são sempre classificáveis em verdadeiras ou falsas, ou está certo ou errado, verdade ou falsidade. Mas segundo Nílson José Machado (2011, p. 34):

[...] apenas sentenças que podem ser classificadas precisamente em verdadeiras ou falsas são admitidas pela porta da lógica formal no discurso matemático. Esse procedimento seletivo garante a monossemia de tal discurso, eliminando as ambiguidades, mas também exclui de seu raio de ação sentenças exclamativas, imperativas ou interrogativas, bem como certa riqueza na diversidade de planos 
de interpretação, frequentemente presentes na linguagem usual.

Para a comunidade científica, segundo Machado (2011, p. 35):

\begin{abstract}
hoje não parece mais haver dúvidas sobre a existência de limitações no raio de ação da Matemática nesse sentido estrito de exatidão que estamos examinando, bem como de outras limitações intrinsecamente associadas aos formalismos em geral. Ser ou não ser onda ou partícula era a questão quando se discutiu, no século XVII, a natureza da luz; mais modernamente, sabemos que a resposta a tal questão transcende em muito o âmbito de uma frase do tipo "isto é (ou não é) aquilo"
\end{abstract}

Ou seja, esta particular exatidão no discurso matemático vem do modo como se particularizam as noções abordadas na lógica formal clássica, que não considera a possibilidade de um talvez, garantindo assim a certeza de todas as afirmações que derivarem daquilo que é axiomatizado. Este raciocínio baseado em postulados e implicações é o mais utilizado na maior parte do estudo de Matemática na Escola Básica. Não é de se surpreender que o aluno tenha a falsa ideia de uma exatidão demasiada na Matemática, já que a Matemática que ele conhece é em grande parte assim: baseada em ideias que perduraram por gerações e onde só se reproduz, sem se criar ou concluir novas propriedades.

Esta visão não é a mais abrangente, as pesquisas na Matemática avançam a cada dia e cada vez mais precisamos abrir nossos próprios olhos para novos horizontes. Um exemplo de uma grande quebra de paradigma foi o das geometrias não euclidianas, que começaram a ser mais relevadas e discutidas no século XIV com a ideia da negação do postulado das paralelas por Nicolai Lobachevski: "Por um ponto fora de uma reta dada passa mais de uma paralela a essa reta." (DEVITO, A.; FREITAS. A; K; PEREIRA, K. C., p. 13) Este postulado alternativo para o usual de Euclides unido dos outros postulados anteriores é capaz de embasar uma nova geometria que foi chamada de geometria Hiperbólica, uma teoria paralela (usando o sentido não geométrico da palavra) que mostra que a pergunta "duas retas paralelas possuem interseção?" pode ser corretamente respondida tanto com sim quanto com não, dependendo do que se considera anteriormente. Esta também é uma pergunta respondida de forma não binária, um tipo de raciocínio já considerado em novas pesquisas na lógica, seja considerando uma terceira resposta (o talvez) ou uma infinidade delas (na lógica fuzzy). Estas novas ideias sobre a geometria, que iam contra a geometria euclidiana usual foram muito debatidas pela comunidade científica da época, era considerado quase que um ultraje de parte de Lobachevski em negar o postulado das paralelas de Euclides, mas a continuidade destes 
estudos nos deu muito mais terreno novo para explorar e a possibilidade de compreender novas geometrias como a hiperbólica e a esférica, além de expandir nossa noção de ponto, reta e plano, já até comparados a mesas, cadeiras e canecas de cerveja (HALSTED, 1895). Mas este é um outro caso em que os avanços no pensamento matemático e suas consequências não são devidamente disseminadas para a população, gerando dificuldades em alcançar novas conclusões e segregando mais ainda as "pessoas comuns" e os "matemáticos". Exemplos como estes são importantes de serem considerados em nossa postura da construção do conhecimento matemático, assim como o historiador e o geógrafo possui um momento ou outro para conversar sobre o passado de um objeto de ensino, os professores de matemática também podem apresentar a seus alunos ao menos curiosidades do mundo matemático mais recente que o grego, uma tentativa de contextualizar um pouco mais um conteúdo matemático, buscar um grau menor de abstração e um maior de cativamento.

Mesmo que existam estudos mais abrangentes e ideias mais abertas na Matemática, estas possivelmente encontrarão muitas dificuldades para se sedimentar em nosso dia a dia escolar, de modo que o trabalho do professor de passar ideias para seus alunos, escrevendo de maneira clara e bem elaborada e cobrando tal escrita dos mesmos pode ajudar a prepará-los melhor para o futuro. Ainda assim, há diferenças na escrita da Matemática e da Língua Materna, que mesmo impregnadas uma da outra, seguindo as ideias de Nílson José Machado, necessitam de um tratamento diferente, esta inegável impregnação não é o suficiente para evidenciar porque apesar de ambas as áreas da ciência serem consideradas indispensáveis para o desenvolvimento do ser humano em sociedade, já que são as matérias mais fundamentais de qualquer grade curricular, ainda assim possuem grupos totalmente diferentes de simpatizantes e comumente são relembradas com sentimentos diferentes por aqueles que já concluíram o ensino básico. É preciso considerar tanto as similaridades quanto as diferenças uma da outra., para tanto é necessário definir melhor algumas noções um pouco distantes do estudo costumeiro de matemático, as de Língua, Linguística e Linguagem.

\subsection{LÍNGUA, LINGUÍSTICA E LINGUAGEM}

Os estudos do naturalista inglês Charles Robert Darwin mostram que os seres vivos 
apresentam relações que os ligam uns aos outros, muitas vezes se adaptando melhor para um determinado ambiente ou situação em que se encontram, ao longo do tempo podendo se reconstruir ou mesmo se remodelar num longo processo guiado pela seleção natural. Algo parecido ocorre, numa velocidade muito mais acelerada, com a linguagem baseada na lingua, o objeto de estudo da linguística. Antes de mais nada é importante definir bem estes três termos, que normalmente não estão no escopo dos trabalhos de pesquisa em matemática:

- Linguística: O estudo científico da linguagem humana (MARTINET, 1978, p.1), seus objetivos como ciência são o de descrever e analisar as operações e processos que são fundamentais para a linguagem humana.

- Linguagem: Fundamentalmente refere-se a um modo de comunicação, seja a dança de uma abelha, o latido de cachorros entre uma vizinhança suburbana ou um eloquente discurso em praça pública. A linguagem desenvolvida por e para humanos é o objeto de estudo da linguística. Em relação ao termo linguagem, também é possível que se refira à capacidade dos humanos de aquisição de um sistema de comunicação, mas esta segunda definição só será utilizada neste trabalho caso mencionada especificamente.

- Língua (ou língua natural, língua humana, idioma): Um tipo de meio de comunicação desenvolvida naturalmente pelos seres humanos. Neste contexto estão inclusas as línguas de sinais, faladas e escritas, mas neste trabalho consideraremos como objeto de estudo somente os aspectos falado e escrito, com maior ênfase no segundo, devido a um maior intricamento entre a escrita em Língua Materna e a escrita na Matemática. Existem também as línguas artificiais como a computacional, sua diferença para com as línguas naturais é a de que estas tem a evolução conforme o passar do tempo como a mais responsável causadora de seu crescimento e mutações enquanto que as computacionais são concebidas de uma maneira mais enxuta, para obedecer propósitos mais específicos, sem uma grande variação conforme o tempo passa.

As definições acima estão baseadas nas encontradas no texto de David Crystal (2010).

Segundo Alan Motta (2015) "De modo bem resumido, a língua é formada por dois elementos: os itens lexicais e a sintaxe. O item lexical é a palavra e a sintaxe é a forma como nós concatenamos, ou seja, juntamos essas palavras." portanto, temos que a língua, um dos 
modos de comunicação entre seres humanos, possui as partículas (não necessariamente atômicas) chamadas de palavras. Estas palavras são então concatenadas de formas específicas de modo da gerar significado e realizar a transmissão de ideias de um locutor para um interlocutor, num processo entendido como linguagem, que é o objeto de estudo da linguística. Esta definição será a utilizada de modo geral neste trabalho e outros pormenores que, com certeza, existem serão desconsiderados por estarem além do escopo deste texto em particular.

Outro ponto que será abordado neste trabalho é a dupla articulação da linguagem. Segundo Vânia Duarte, a língua se divide na primeira e na segunda articulação. A primeira diz respeito a associação de signos linguísticos numa certa ordem. Estes signos são dotados de um significante, a representação do objeto que se representa, em nosso caso as letras do nosso alfabeto; e significado, ou seja, o representado, a ideia relacionada às letras e palavras. Estes signos são concatenados em sequências que possuem coerência e coesão. Ao se escrever a palavra gato, não podemos utilizar as letras na ordem ogat, isto vai contra a primeira articulação que rege que a palavra gato possui uma ordem específica de escrita de seus signos. Da mesma maneira, ao se declarar a frase:

Eu gosto de gatos.

Não é possível fazê-lo numa ordem qualquer, como

.gatos gosto de $\mathrm{Eu}$

A primeira articulação da língua, resumidamente, rege como se ordena estes elementos na escrita. Esta regência está presente tanto nas partes de uma palavra quanto nas partes de uma sentença, oração, parágrafo ou texto. Já a segunda articulação da língua é similar à primeira, mas relacionada aos fonemas e sons que se atribui aos signos anteriormente discutidos. É importante evidenciar que a Língua Materna é uma linguagem duplamente articulada, provida de escrita e fala, ao mesmo tempo que a Matemática, segundo Machado: "(...) não comporta a oralidade, caracterizando-se como um sistema simbólico exclusivamente escrito" (MACHADO, 2011. p. 111) ou seja, só possui a primeira articulação. Mas como então é possível ler uma sentença matemática em voz alta e compreender seu significado? Nílson José Machado afirma que isto se dá ao fato de que a Matemática empresta da Língua Materna a oralidade: Você está lendo na Língua Materna algo representado em outro sistema de representação. Isto é similar ao que ocorre quando se multiplica matrizes quadradas: ao se operar o objeto matrizes, dentro do anel das matrizes, é necessário realizar 
operações de números reais, dentro do anel dos números reais. Nestes dois casos estamos realizando uma operação em um sistema de representação dentro de uma outra operação de um outro sistema de representação.

Para melhor compreender como se dá a ordenação dos elementos de uma oração, seja ela em Língua Materna ou uma sentença Matemática, vamos nos aprofundar numa parte da linguística que trata destes conceitos e concatenação dos elementos conforme a primeira articulação da língua.

\title{
1.4 GRAMÁTICA GERATIVA
}

Em seus estudos, Machado buscou explicitar as particularidades de diversos slogans, frases de efeito, sintéticas e socialmente aceitas como verdade, e entre estes estava a frase "a matemática desenvolve o raciocínio.” Nílson José Machado (2011, p. 83) então propõe que

\begin{abstract}
para que resulte mais clara a questão que se analisa, com todas as letras é bom que se afirme que não está em discussão o fato óbvio de que o ensino da Matemática contribui para o desenvolvimento do raciocínio. Na verdade, o ar que respiramos ou os alimentos que nos mantêm vivos também contribuem para isso. O que se questiona é o superdimensionamento do papel da Matemática, ou mesmo uma suposta exclsuvidade às vezes insinuada na associação entre este assunto e o desenvolvimento do raciocínio.
\end{abstract}

E afirma então que o raciocínio é desenvolvido por qualquer atividade cognitiva realizada por um indivíduo, mas seu principal ordenador é a Língua Materna: por estar presente na leitura, ela se entrelaça de uma maneira singular ao modo como se concatenam ideias num indivíduo. Conforme suas próprias palavras:

(...) a matemática, a despeito de sua contribuição singular, de grade importância e irredutível a da Língua Materna (...) caracteriza-se como fonte secundária para o raciocínio lógico. Por mais óbvio que possa parecer, insistimos em que, nesse contexto, secundária não significa de menor importância, mas apenas que surge em segundo lugar, inclusive sendo influenciada pela fonte primária. (MACHADO 2011, p. 83)

O raciocínio, assim como a própria Matemática, está ancorado na língua para que possa tomar forma e ser articulado. Devido a esta forte ligação, o modo de raciocínio difere muito entre pessoas oriundas de diferentes partes do mundo devido às diferentes Línguas Maternas: os países ocidentais, e suas línguas normalmente indo-europeias, seguem caminhos diferentes de raciocínio quando comparados com a China, de língua sino tibetana, ou o Japão, 
cuja língua se desenvolveu com influências do idioma chinês, a gramática coreana e um maturamento isolado de ambos. Para exemplificar estas diferenças, vamos analisar a oração a seguir em duas línguas diferentes:

Kaori gosta de matemática.

No português, temos que o sujeito da frase (Kaori) pratica a ação de "gostar," indicada pelo verbo em sua forma conjugada no presente do indicativo, para com o objeto "matemática", completando o sentido e ideia que se quer transmitir. O sujeito (quem) pratica uma ação transitiva (que necessita de complemento, no caso gostar) para com um objeto sobre o qual é exercita a ação (matemática). Este tipo de análise é conhecido como análise sintática. $\mathrm{Na}$ sua versão japonesa, a frase

Kaori wa suugaku ga suki. (Kaori gosta de matemática)

é analisada da seguinte forma: o sujeito (Kaori) é relacionado com o outro objeto (suugaku, que significa matemática, ou mais precisamente, o estudo [gaku] de números [suu]) através das partículas $w a+g a$ (que neste contexto relacionam objetos e sujeitos a uma ação) com a ação de gostar (suki). No português um sujeito está praticando uma ação sobre um objeto, enquanto que no japonês, este sujeito, o objeto e a ação estão relacionados. Ambas passam o mesmo sentido e alcançam os mesmos objetivos em termos de comunicação, mas o modo como o fazem difere muito: as línguas indo-europeias giram em torno do(s) verbo(s) de ligação, no português: ser, estar, etc; no inglês o verbo to be, entre outros. Enquanto isso, nas línguas orientais as ideias se passam através de relações entre sujeitos e/ou objetos. Também é importante notar a diferença na ordem em que os elementos se apresentam em ambas as orações.

Esta diferença no pensamento e na ordenação se reflete em matemática, por exemplo, na relação de igualdade: para um estudante brasileiro, por exemplo, é influenciado pelo raciocínio costumeiro na ordem sujeito $\rightarrow$ verbo $\rightarrow$ predicado, as sentenças $\mathrm{x}=1$ e $1=\mathrm{x}$ parecem ter significados diferentes, sendo a primeira a forma mais comum na sala de aula onde geralmente se trabalha com a incógnita à esquerda e, quando depara-se com a segunda, como que uma forma estranha e incômoda, alheia ao esperado numa equação matemática, comumente se utiliza uma outra passagem para se retornar à forma "normal". Enquanto isso, para um estudante japonês, a frase $\mathrm{x}=1$ indica que os objetos incógnita $\mathrm{x}$ e número 1 se relacionam por uma igualdade, partilhando assim do mesmo valor e significado. Essa diferença vem do enraizamento entre a Língua Materna, que além de dar oralidade à linguagens que não são dotadas da mesma, partilha da sua maneira de raciocinar própria, e 
embrenha-se discretamente em nossa cognição.

Machado conclui que

(...) em cada cultura, a forma como o pensamento se organiza está diretamente relacionada com as estruturas básicas da Língua correspondente. No desenvolvimento do raciocínio lógico, a Língua Materna funciona, indubitavelmente, como a fonte primária , com uma importância no ensino básico que transcende em muito a da própria Matemática. Assim, a adesão ao slogan "A Matemática desenvolve o raciocínio", com todas as conotações que lhe são peculiares, deveria exigir bem mais cautela do que costumeiramente exige(MACHADO, 2011, p.90)

Isso mostra o quanto a Língua Materna influencia nossa organização de pensamento: é a partir dela que ordenamos as ideias e construímos argumentos. Uma frase, mesmo que sendo raciocinada em Matemática, necessita de uma conexão com a Língua Materna para ser oralizada, mesmo que mentalmente, e portanto se torna embrenhada de sua própria maneira de escrita, entretanto ideias como a da igualdade, que vai contra a sequência sujeito $\rightarrow$ verbo $\rightarrow$ predicado, assumindo uma forma de objeto $\rightarrow$ relação $\rightarrow$ objeto, podem exigir uma maior desenvoltura para serem realmente compreendidas, ou correm o risco de serem compreendidas apenas de uma forma rústica que poderá se tornar um potencial empecilho para a compreensão de tantos outros raciocínios e conteúdos de cunho matemático que por si só já apresentam dificuldades próprias.

A ordem de concatenação de elementos da língua é objeto de estudo da Gramática Gerativa, teoria da linguística elaborada por linguistas do Massachusetts Institute of Technology e tem como elaborador principal o linguista estadunidense Noam Chomsky, nascido no ano de 1928 na Filadélfia. Ele é considerado um dos maiores revolucionários na área da linguística e possui inúmeras contribuições no campo, principalmente no seu modelo de gramática apresentado no livro Aspects of the Theory of Syntax de 1965, onde ele dá os fundamentos da gramática gerativa padrão, que foi estendida nos anos seguintes, para então, na década de 80 , ser reformulada como modelo de "princípios e parâmetros" e no final da década de 90 entra em sua fase conhecida como "programa minimalista", o modelo atual de gramática gerativa. Esta última forma mantém as ideias fundamentais da gramática gerativa:

- todos os humanos possuem uma predisposição inata a aprender uma língua;

- todas as produções em qualquer língua são geradas a partir de um componente computacional comum a todos os humanos, chamado de gramática universal. 
Nesta gramática gerativa, há três grandes vertentes de estudo:

- Fonologia: os sistemas que regram a formação de frases a partir de sons e signos fônicos, os fonemas;

- Sintaxe: os sistemas de regras e relações que definem e interpretam a formação das frases primordialmente em sua forma escrita;

- Semântica: as regras e o estudo da interpretação destas frases.

Para Chomsky (1965), a gramática é uma ciência que discute aspectos da língua e seu falante, que é capaz de emitir e compreender frases nunca antes vistas devido às relações entre os objetos e conceitos utilizados. Além disso, a gramática possui um número finito de elementos, mas como eles podem ser concatenados de maneiras ilimitadas, considera-se que pode emitir um conjunto infinito de sentenças diferentes, mas todas têm uma sequência bem definida e são compreendidos por regras já internalizadas por seus usuários. Durante nossos estudos, e pela ausência de uma oralidade na matemática, daremos mais ênfase à vertente sintática da gramática, ou seja, a estrutura das frases que consideraremos e analisaremos.

Segundo a gramática gerativa minimalista de Chomsky (1995), a ordem sujeito $\rightarrow$ verbo $\rightarrow$ predicado e objeto $\rightarrow$ relação $\rightarrow$ objeto utilizada anteriormente é mais bem definida como sendo a ordem SVO (sujeito, verbo, objeto) e SOV (sujeito, objeto, verbo), respectivamente. As línguas indo-europeias são predominantemente da ordem SVO, enquanto que o japonês e o chinês são considerados como sendo línguas de ordem SOV, mesmo que eles não apresentem necessariamente o verbo per se. Por exemplo, a oração em japonês :

Watashi wa Danieru desu. (Eu sou o Daniel)

Possui as seguintes partículas:

- Watashi (Eu, usado por mulheres ou homens adultos)

- $\quad w a$ (partícula conectiva sem tradução que liga o sujeito "eu" ao objeto "Daniel")

- Danieru (forma como o japonês interpreta o som do nome próprio Daniel)

- $\quad \operatorname{desu}$ (caracteriza a frase como afirmativa)

Em especial a partícula desu não é necessariamente um verbo mas indica a ação da frase, por exemplo, caso fosse utilizada a partícula desuka, que indica a forma interrogativa, a 
frase teria o sentido de “eu sou o Daniel?", mesmo não havendo o símbolo tradicional de interrogação "?". Esta frase possui o mesmo significado que a sentença equivalente em português, mas diz a mesma coisa de uma maneira diferente, já que os pensamentos e maneiras de interpretar o mundo pelos orientais e ocidentais possui tênues diferenças devido à maneira como as suas Línguas Maternas se constroem. Segundo o filósofo chinês Chang Tung-Sun:

\begin{abstract}
(...) quando dizemos, por exemplo, "isto é amarelo e duro", a "amarelidão" e a "dureza" constituem os chamados atributos de uma coisa, quer no caso presente é "isto". A "coisa" geralmente é o substractum. Com o substractum surge a ideia de "substância". A ideia é, na verdade, o fundamento ou a fonte de todos os outros desenvolvimentos filosóficos. Havendo uma descrição qualquer, ela passa a ser atributo. Um atributo deve se atribuído a uma substância, de modo que a ideia de substância é absolutamente indispensável ao pensamento assim como o sujeito é absolutamente indispensável à linguagem. Por isso, na história da Filosofia Ocidental, por mais diferentes que possam ser os argumentos, favoráveis ou contrários à ideia de substância, o que constitui o problema central é essa mesma ideia de substância (apud CAMPOS, 1977, p. 204).
\end{abstract}

As noções de substância e atributo de Chang Tung-Sun podem ser entendidas com as utilizadas até o momento, respectivamente, de sujeito e objeto? A maneira como estes sujeitos e objetos se relacionam toma uma ideia de posse no pensamento ocidental e de relacionamento no pensamento oriental, mas serão somente palavras similares? Novamente citando este filósofo chinês, este afirma que:

A proposição com sujeito e predicado dá origem aos conceitos filosóficos de substância e atributo. $\mathrm{O}$ estudo da substância leva à concepção de ser supremo em religião e de átomos em Ciência. Do conceito de substância derivou a ideia de casualidade, que por sua vez dá origem à Ciência. De modo que as categorias do pensamento ocidental são identidade, substância e casualidade, determinadas talvez, todas as três, pelo padrão das sentenças nas línguas ocidentais (apud CAMPOS, 1977, p. 246)

Portanto nossa maneira ocidental de conceber uma linha de raciocínio baseada em sujeitos e suas qualidades, substâncias e seus atributos, vem principalmente de nossa ordenação de raciocínio e modo de comunicação baseada em sujeitos e predicados. Essa ordenação deve ser tomada com parcimônia durante estudos, pois segundo Machado

A despeito da necessidade de cautela para que sínteses de aparência tão fecunda não degenerem em mero mecanicismo no estudo das determinações da Lógica pela Língua, hoje já parece indiscutível o fato de que o pensamento oriental e ocidental ostentam molduras lógicas substantivamente distintas. Em tempos recentes, a própria Ciência Ocidental, sobretudo através da moderna Física das partículas, tem ensaiado a incorporação de algumas características do modo de pensar oriental, em razão de certas questões embaraçosas, para as quais o 
pensamento ocidental limitou-se a conceder não ter registro. (MACHADO,2011, p. 89)

Devemos então ter a cautela de considerar tanto a posição do pensamento ocidental quanto a do oriental, mas não reduzir estas considerações a propriedades estáticas e definitivas, pois é exatamente isto que a Língua não é, ao se reestruturar e remodelar a todo instante, como que algo vivo que caminha junto à sociedade. Uma prova desta reestruturação é a própria iniciativa do pensamento ocidental científico em tentar assimilar conceitos orientais para melhor compreender o mundo a sua volta. Talvez novamente possamos considerar os diferentes modos de pensar de pessoas ao redor do mundo como maneiras diferentes de tentar compreender o ambiente em que vivemos, assim como diferentes representações de um mesmo representado, como as ideias de Duval para aprendizagem, e novamente estaríamos aplicando a tão concisa e poderosa ideia de que sem noésis não há semiósis: teríamos então uma maior e melhor compreensão ao transitar nosso pensamento entre o oriental, ocidental ou até mesmo outras maneiras de estruturar nossa lógica, traduzindo um pensamento entre estas representações diferentes de modo a sorver a maior parte possível do objeto em questão. Mais sobre o pensamento Oriental e o Ocidental pode ser encontrado no texto de Capra (995)

\subsection{LÍNGUA MATERNA E MATEMÁTICA}

Os estudos de Nílson José Machado sobre os slogans comumente utilizados pela população brasileira também levaram em consideração o dilema do "para que serve" um ou outro determinado conceito matemático. Esta é uma pergunta que muito possivelmente todo professor de Matemática já ouviu, é óbvio que o método de se obter raízes de um polinômio de segundo grau ou operações de multiplicação entre matrizes são conhecimentos um tanto quanto distantes do dia a dia da maior parte da população, mas ainda assim estes conhecimentos são parte do conteúdo presente no ensino brasileiro. Muitas vezes responde-se a pergunta do "para que serve" com uma enunciação da metáfora do usuário, em que os não especialistas utilizam-se de algo assim como o cidadão comum dirige um carro: não conhecendo praticamente nada sobre seu funcionamento interno ou construção, somente um mínimo necessário para usufruir do objeto em questão. Poderemos então seguir uma carreira 
não necessariamente matemática sabendo somente algumas operações e relações mais memoráveis e descartar completamente o restante das aulas que assistimos? Utilizando-se das palavras de Machado, quando afirma que:

[...] é possível utilizar-se de um código levando-se em consideração apenas sua dimensão sintática, o mesmo podendo concorrer com uma linguagem formal; no entanto, conforme já foi examinado, a Língua não se restringe a um código, embora não prescinda de um, assim como a matemática não se restringe a uma linguagem formal, ainda que não possa prescindir de uma. Em consequência, quando se atribui tanto à Língua como à Matemática o estatuto de sistemas de representação, a metáfora do usuário parece resultar inteiramente inadequada." (MACHADO, 2011, p. 121),

Temos que o foco não é questão de lembrar dos conteúdos específicos como a divisão de polinômios, mas sim dos pontos mais internos dos raciocínios utilizados: a Língua e a Matemática não se restringem somente a um código, somente a uma concatenação de elementos seguindo uma sintaxe específica, mesmo necessitando de uma para existir, elas tomam horizontes mais distantes de serem somente uma maneira de apresentar um raciocínio já que são embrenhadas em nosso modo de pensar, assim como nenhuma geometria pode prescindir de axiomas, nossa maneira de compreender o mundo necessita de uma base em que possamos então desenvolver maneiras de internalizar informações, processá-las e externalizar um produto final.

Como a matemática, assim como a Língua materna, pode ser interpretada como um sistema de representação, aqueles que possuem a base para se compreender outros objetos, não podemos nos utilizar da metáfora do usuário quando aprendemos a calcular raízes de polinômios, a operar matrizes e outras partes do estudo de matemática, pois estamos, na realidade, nos apropriando de diversos conceitos e raciocínios que, estes sim, estarão amplamente presentes em nosso dia a dia, sejam estes os próprios conceitos e raciocínios in natura ou em expressões da língua materna como "dar as coordenadas", "chegar a um denominador comum", "sair pela tangente", "ver de um outro ângulo", "o círculo íntimo", e tantas outras, embrenhadas de matemática e seus termos particulares. Não podemos aprender a ler somente reproduzindo frases que sabemos que são corretas, é necessário saber articular os elementos de uma sentença para que ela reflita nossas intenções e comunique o que deve ser comunicado, assim como não podemos aprender matemática somente utilizando algoritmos pré estabelecidos e repetições sem sentido, é necessário entender um mínimo de 
ambos os assuntos, é mais importante saber qual procedimento deve ser feito para solucionar um determinado problema do que efetivamente realizar cada operação matemática necessária para tal, principalmente na atualidade, em que a maior parte dos cálculos é feita por instrumentos como calculadoras e computadores.

Mas é a matemática restrita somente a realizar os cálculos necessários para solucionar um problema? É a Língua materna necessária unicamente para se comunicar com outros indivíduos? Estes podem ser alguns dos principais motivadores destas ciências, mas é crucial compreender que ambas possuem muitas outras finalidades, além de que não é necessário segregá-las tanto, seja em seus objetivos, ou seja, em sua própria posição como ciência. A língua materna e a matemática normalmente são tratadas de maneira distante uma da outra, mas estão intrinsecamente ligadas e unidas. Esta posição de não distanciamento é amplamente abordada por Nílson José Machado que chama esta ligação de uma impregnação mútua, onde uma ciência se entrelaça à outra profundamente, segundo ele:

\begin{abstract}
De fato, no nível do senso comum, a associação da Matemática a números ou a relações quantitativas parece natural e incontestável. Ao deparar com resultados de natureza qualitativa como os que soem ocorrer em Topologia, o homem comum até reluta em reconhecê-los como matemáticos. Com efeito, proposições como as que afirmam a equivalência topológica entre a esfera e o cubo, ou entre signos "A" e "R", ou entre o "F" e o "T", ou a não equivalência entre uma xícara e um copo, ou entre o "O" e o "Q", são mais facilmente associados a curiosidades ou brincadeiras do que à legítima Matemática. (MACHADO, 2011, p. 126)
\end{abstract}

De modo que o cidadão comum tende a separar demasiadamente as áreas do conhecimento nos termos exatas, biológicas e humanas, formando barreiras mentais que o impedem de compreender nuances como a "inexatidão" da matemática, no sentido de que nem tudo no mundo matemático é verdadeiro ou falso, nem tudo pode ser demonstrado, haja vista a famosa demonstração da indemonstrabilidade em alguns sistemas formais proposta por Gödel em 1931 que derrubou as pretensões do formalismo absoluto na matemática, mostrando então que a Matemática é uma ciência onde não somente números existem; na verdade quanto mais avançada é uma determinada aula de matemática, menos "números" costumam estar presentes na lousa, e mais objetos variáveis ou arbitrários representados por outros símbolos que não os algarismos indo arábicos. Ao mesmo tempo, a Língua Materna se mostra em parte determinística, exata, em momentos como a gramática, interpretação de orações e padrões, um exemplo claro é a capacidade de se separar os elementos diferentes da Língua em categorias como verbo, adjunto adverbial, vocativo e tantas outras.

Mas se não são tão diferentes, devemos unir a Matemática e a língua materna e tratá- 
las de uma maneira única? Segundo Machado:

(...) nenhuma das numerosas tentativas levadas a efeito até hoje de tratar a Matemática como uma Língua, ou uma Língua como Matemática, chegou a bom termo ou estabeleceu raízes fundas. Condillac, por exemplo, com sua Língua dos Cálculos não logrou alinhavar senão um arremedo de Matemática. Analogamente, os diversos responsáveis pelas tentativas de construção de uma língua universal foram, em sua maioria, seduzidos pela perspectiva de criar uma língua sem ambiguidades, com uma gramática inteiramente lógica, que funcionasse de modo análogo à Matemática. Raríssimos foram os casos em que tais tentativas sobreviveram ao entusiasmo de seus criadores e nenhuma delas logrou alcançar o estatuto de uma verdadeira língua. (...) A nosso ver, é precisamente a ignorância da complementaridade nas funções a serem desempenhadas pela Língua Materna e pela Matemática a razão determinante do indiscutível fracasso de todas essas tentativas. A compreensão desse fato é absolutamente fundamental para evitar a tentação de superação das dificuldades com o ensino através do elogio entusiasmado de qualquer um dos dois sistemas, em detrimento do outro. (MACHADO, 2011, p. 133-134)

Não estamos buscando uma língua babélica e utópica, capaz de unir a capacidade de transmissão de ideias extremamente diversas da Língua Materna, mesmo que entre os seus falantes, com a capacidade de transmitir ideias mais restritas, mas com um número maior de "falantes", independente de suas Línguas Maternas, como é o caso da Matemática, cujos objetos independem do idioma em que são representados. Uma união como essa, como diz Nílson José Machado, até o momento só resultou em fracassos, como que unindo somente as partes restritivas destas duas ciências, ao invés das desejadas em suas construções. Não estamos tentando analisar a Matemática como uma Língua ou a Língua Materna como uma linguagem lógica formal, mas sim tentar compreender o que essa impregnação entre ambas pode nos auxiliar na transposição de um objeto matemático da comunidade científica até o ensino básico, pois já que existe esta impregnação, e a grande maioria de nossos alunos são falantes de Língua Portuguesa, parece natural que consideremos mais do que somente a Matemática no desenvolvimento de uma notação para um objeto matemático.

A impregnação mútua entre a Matemática e a Língua Materna se dá em dois pontos principais, como destacado por Machado (1991):

- A Matemática empresta da oralidade da Língua para dar som ao seu próprio código, por não ser uma duplamente articulada como descrito no item 1.3 deste trabalho.

- Ao mesmo tempo que aparentemente a Matemática tem uma característica de síntese, partindo do geral para o particular e mais aspectos quantitativos, e a Língua toma o sentido oposto, indo da unidade para o caso geral, apresentando mais aspectos qualitativos, na verdade ambas possuem tanto uma parte sintética quanto uma generalizante, além de aspectos 
quantitativos e qualitativos.

Neste segundo ponto, a impregnação se dá na Língua Materna, por exemplo, ao se usufruir de raciocínios comuns da Matemática para se expressar, exemplos claros são "dar as coordenadas", "chegar a um denominador comum", "sair pela tangente", "ver de um outro ângulo", "o círculo íntimo", onde não se está literalmente saindo por uma reta tangente a um certo ponto, ou relatando coordenadas num plano cartesiano ou mesmo interpretando pontos de vista diferentes como frações para que possamos compará-las sob um mesmo denominador, mas na verdade estamos nos apropriando de expressões provenientes de raciocínios de cunho matemático, mesmo que num novo sistema de representação, e distante dos objetos usuais a quais esses raciocínios são aplicáveis (retas, pontos, planos e frações nos casos acima). Por sua vez, a impregnação da Matemática pela Língua Materna se dá na maneira de se comunicar uma sentença matemática. Podemos entender o processo como um indivíduo bilíngue que lê uma sentença numa determinada língua, traduz esta sentença para sua língua materna, processa as informações numa resposta, traduz esta resposta novamente para a língua inicial e então responde a sentença original.

Um exemplo da minha experiência em ensino em que isto se mostra evidente é na resolução apresentada por um aluno diante a resolução da operação $3 \times 4+2$, onde ele escreve:

$$
3 \times 4=12+2=14
$$

O que é uma falácia no sentido que $3 \times 4 \neq 14$, mas quando lemos esta resolução da operação em voz alta, aproveitando da maior proximidade com a Língua Materna, podemos mais facilmente compreender a oração como sendo: "três vezes quatro é 12, mais dois é catorze" e então é possível claramente ver o raciocínio seguido pelo estudante. Este raciocínio é proveniente de uma mistura de linguagem matemática e linguagem materna, onde propriedades de ambas se misturam e se entrelaçam. 
Figura 1 - Processamento de uma sentença em outra língua

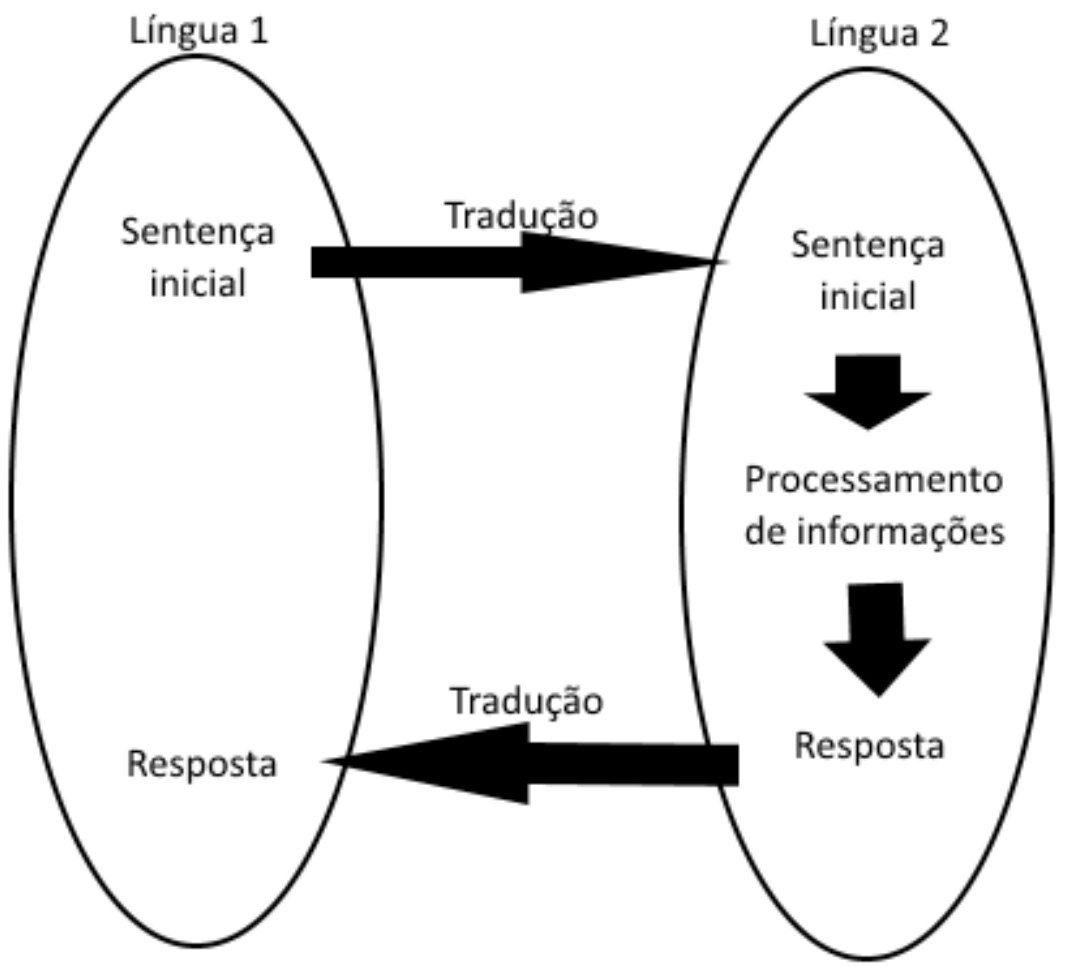

A partir do esquema representado na figura 1 e as proposições de impregnação da Língua Materna e Matemática, temos que se este aluno, mentalmente, primeiro usou a linguagem da Língua Materna (Língua 1) traduzindo a sentença inicial para uma em matemática para poder operar os objetos matemáticos, ou seja, realizar as operações matemáticas de multiplicar e somar, seguido de representar seu resultado final com uma igualdade. Esta primeira leitura é muito rápida e a "tradução" para a sua versão matemática é quase que instantânea neste caso. Em seguida o aluno traduzirá a sentença de volta para uma língua capaz de oralizar esta informação, caso verbalize-a, ou mesmo escreverá a sentença diretamente utilizando o código matemático. Portanto uma resolução oral de uma operação matemática necessita de duas traduções entre sistemas de representação diferentes representadas pelas setas horizontais da esquema acima. Estas traduções até podem ser simples para um número pequeno de operações, mas como a matemática não possui uma oralidade, se tornam praticamente impossíveis para cálculos mais extensos, como calcular o determinante de uma matriz $4 \times 4$ ou escalonar um sistema de muitas equações. $\mathrm{O}$ registro escrito em matemática tem um valor acima do normal por ser o principal meio de processamento de informações permitido por essa linguagem formal.

Tendo então uma maior noção da impregnação da Matemática e da Língua Materna, é 
necessário dar uma atenção maior então ao modo como um conhecimento transita entre ser um objeto de estudo da comunidade científica, ser considerado conhecimento necessário para a população geral e então ser configurado para o ensino na Escola Básica. Este processo será descrito a seguir.

\subsection{TRANSPOSIÇÃO DIDÁTICA}

Quando se fala do caminho percorrido pelo objeto de estudo durante o processo de aprendizagem, seja a forma como se aborda o conteúdo ou das transformações que o mesmo sofre para transitar de um ambiente de pesquisa para a sala de aula, torna-se necessário distinguir duas palavras normalmente utilizadas como sinônimo. Segundo Luis Carlos Pais (MACHADO, S. D. A. et al. 2010 , p .12), quando tratamos de um saber, estamos nos referindo a um objeto mais descontextualizado, despersonalizado e generalizado, mais próximo dos pesquisadores do que dos alunos, visualizado de uma maneira mais ampla, com mais atenção para o modus operandi e nuances intrínsecas ao conhecimento em questão; por sua vez, o conhecimento é algo mais individual e subjetivo, rico em experiências pessoas e vinculado a um determinado sujeito. Podemos considerar que o conhecimento de cada um pode ser compreendido como a imagem que um determinado indivíduo montou a partir de diversos pontos de vista ao vislumbrar um determinado objeto matemático e a abrangência da capacidade de representar de maneiras diferentes e transitar entre estas representações. A boa formação deste conhecimento é portanto o objetivo do ensino, ou seja, desejamos que seja possível compreender e otimizar a transposição de um saber para um conhecimento num determinado indivíduo, saber este que também não é necessariamente o objeto matemático em questão em sua totalidade, mas sim uma versão mais geral e ampla do que um único conhecimento, formada e aceita pela comunidade científica através de seus estudos.

A noção de transposição didática é o caminho e mudanças que um saber percorre para se tornar um saber a ensinar e finalmente culminar num saber ensinado, onde então se tornará um conhecimento para o aluno. Segundo Chevallard (1991, p. 39)

Um conteúdo do conhecimento, tendo sido designado como saber a ensinar, sofre então um conjunto de transformações adaptativas que vão torná-lo apto a tomar lugar entre os objetos de ensino. $O$ trabalho que, de um objeto de saber a ensinar faz um objeto de ensino, é chamado de transposição didática. 
Este caminho de transformações é de crucial importância para os estudos do ensino de matemática, por revelarem as influências que o saber científico causa no saber escolar a ser ensinado, estas influências são inevitáveis e positivas e agem como uma aproximação do aluno da escola básica ao pesquisador das universidades mas devem ser tratadas com cuidado para se evitar excessos de formalização e conteúdo desnecessário para o aluno, o que pode levar a métodos ineficientes de ensino. É preciso tanto considerar os interesses da sociedade que necessita do cidadão em seu meio quanto do estudante, que precisa de um estudo significativo e tanto envolvente quanto possível. Em relação à sociedade que possui os interesses e motivações para que certos conhecimentos sejam ou não sejam abordados no ensino da Escola Básica, segundo Luiz Carlos Pais (MACHADO, S. D. A. et al. 2010, p. 16)

\footnotetext{
O conjunto das fontes de influências que atuam na seleção dos conteúdos que deverão compor os programas escolares e determinam todo o funcionamento do processo didático recebeu, de Chevallard, o nome de noosfera, da qual fazem parte cientistas, professores, especialistas, políticos, autores de livros e outros agentes da educação. $\mathrm{O}$ resultado do trabalho seletivo da noosfera resume-se não só à determinação dos conteúdos, como também influencia a estruturação dos valores, dos objetivos e dos métodos que conduzem a prática de ensino. Essa é a ideia da transposição didática, entretanto, devemos retornar a ela várias vezes na busca de sua essência.
}

A noção da noosfera nos dá então um ponto de partida para o caminho percorrido pelo saber, mesmo que este exista antes de sequer ser cogitado como um saber a ensinar, no momento em que se explicitam motivos para realizar esta transformação é que um saber começa a ser moldado de forma a eventualmente ser ensinado na escola básica. Portanto há uma presença indispensável dos elementos da noosfera para que esta transição ocorra, seja como motivadora ou mediadora: são os interesses dos cientistas, professores, especialistas, políticos e tantos outros sendo transcritos para o papel, aquilo que é ensinado tem um motivo de ser ensinado, nenhum conteúdo da escola básica se esgueira até os livros didáticos por motivos banais, todos eles são planejados para que se dê tanto uma continuidade quanto uma boa construção seja de base a refinamentos e retomadas de conteúdos vistos anteriormente pelo aluno. Não se ensina um aluno a multiplicar sem que este tenha compreendido e dominado algumas nuances da soma, apesar de que não todas, pois esta será revista e mais profundamente embasada num futuro breve.

O conhecimento adquirido por um aluno não é imutável, especialmente em matemática, onde muitas vezes é visto como uma construção em espiral, periodicamente revendo e retomando noções antigas, remodelando-as para uma noção mais refinada. Na 
verdade o conhecimento em geral não é imutável pois a própria comunidade científica está a todo momento tentando quebrar seus próprios argumentos, o que eventualmente nos levou à quebras de paradigma no passado: quando se percebe que um conceito antes amplamente aceito na verdade era equivocado ou possuía uma visão um tanto quanto estreita, devendo ser revisto desde suas origens para que então seja remodelado e possa voltar a fazer parte da gama de conhecimentos humanos ou possivelmente ser substituído por uma nova ideia, que por sua vez buscará aceitação e tornar-se-á um novo paradigma. Um exemplo clássico desse processo é a ideia do Heliocentrismo, introduzida na antiguidade clássica, amplamente rejeitada e reintroduzida por Galileu Galilei no século XVI, considerado então herege por ser contra o paradigma da época, o Geocentrismo. A ideia foi reformulada diversas vezes, por Nicolau Copérnico, Johannes Kepler e finalmente por Isaac Newton, onde seu modelo da gravitação universal persiste até hoje como ideia amplamente aceita. É interessante notar também que na renascença o Sol deixou de ser o "centro do universo" para se tornar o "centro do nosso sistema solar", o que de certa forma mudou o modo como os "centrismos" eram visto. Além disso o modelo newtoniano já se mostrou ineficiente para objetos massivamente grandes ou infimamente pequenos, sendo substituído pela teoria quântica já em meados do século XX para a comunidade científica, teoria esta que lentamente se aproxima do estudante de ensino básico, mas ainda se encontra um tanto quanto distante do escopo do ensino de física atual.

Não vamos nos aprofundar muito nos detalhes da história da astronomia, pois isto foge dos interesses deste trabalho, mas percebamos o quanto a ideia se alterou no passar dos anos, o quanto se reforma e como é demorado o processo da quebra de um paradigma, pois a teoria newtoniana é amplamente ensinada hoje por ser de fácil compreensão e relativamente mais simples do que a relativística teoria quântica para o aluno da escola básica. O mesmo ocorre em muitos outros pontos do saber, tudo devido ao modo como a noosfera rege os interesses de ensino.

Outra transformação que pode ocorrer com o saber durante o processo da transposição didática e muito presente na matemática é a que ocorre com as criações didáticas, segundo Luiz Carlos Pais (MACHADO, S. D. A. et al. 2010, p. 17) estas criações

Em certos casos, são motivadas por supostas necessidades do ensino para servirem como recursos para outras aprendizagens. A princípio, tais criações têm uma finalidade educacional, entretanto, o problema surge quando seu uso acaba acontecendo de forma puramente automatizada e desvinculada de aplicação. Esse é o caso dos produtos notáveis, que, quando ensinados isoladamente, sem 
nenhuma relação com algum outro conteúdo algébrico ou geométrico, passam a figurar apenas como objetos de si mesmos.

Outro exemplo dado por Luiz Carlos Pais é o dos diagramas de Venn, que são comumente ensinados como sendo a derradeira "visualização" dos conjuntos matemáticos, o que é um equívoco pois estes diagramas nada mais são que uma das maneiras de se interpretar os conjuntos, apesar de mais "sólida" que uma representação mais formal, ela não pode ser de maneira alguma capaz de trazer todas as informações sobre um objeto matemático ao mesmo tempo que o representa, como foi discutido no item inicial deste capítulo sobre sistemas de representação. Os diagramas de Venn, assim como os produtos notáveis, podem se tornar um conhecimento sem ligação com o exterior, sem conexões com outros objetos matemáticos e conhecimentos, em que o aluno não consegue ligar a ideia de $(a+b)^{2}$ ser uma representação de um quadrado de lado $(a+b)$ como na figura a seguir

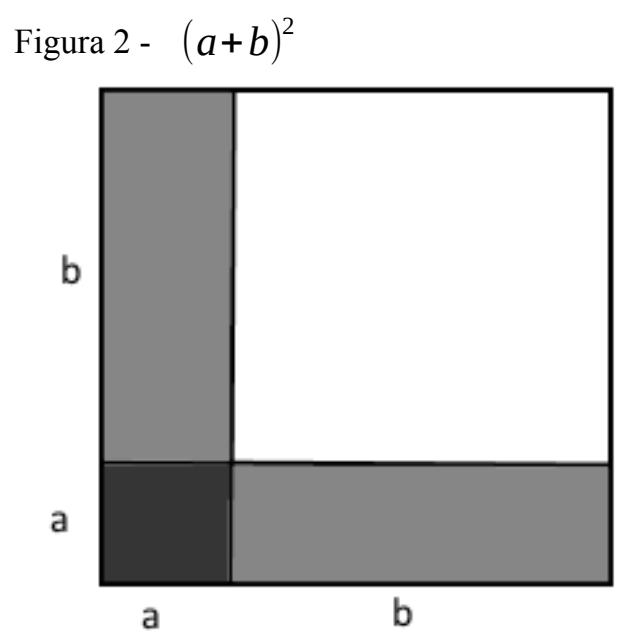

e simplesmente relaciona a expressão $(a+b)^{2}$ com sua forma não fatorada $a^{2}+2 a b+b^{2}$ quase que numa assimilação mecânica entre as duas. Usando os conceitos de sistemas de representação estudados anteriormente, é como se o aluno fosse somente capaz de uma gama finita de pontos de vista do objeto matemático como um todo e não tivesse a capacidade de traduzir uma certa representação em outra, como que fragmentando um mesmo objeto matemático em suas diversas formas de representá-lo e sendo incapaz de relacionar umas com as outras. Um outro exemplo disto aparece claramente quando um aluno considera os números 0,5 e $\frac{1}{2}$ como sendo diferentes, mesmo que representem a mesma quantidade. Esta distorção pode decorrer de um uso constante do objeto em questão de uma forma automatizada e com exercícios de reprodução em que os conceitos fundamentais não são 
retomados, ao se regir o uso do objeto matemático como que uma ferramenta somente, perdese muito de seu sentido e significado. Parte dessa distorção pode vir do modo como alguns conhecimentos são tratados na escola, como cita Luiz Carlos Pais:

\begin{abstract}
A pesquisa realizada por Becker (1997) analisa também a epistemologia do professor no cotidiano escolar. Esse trabalho conclui que o pensamento predominante na prática docente quanto ao significado epistemológico de sua disciplina, é de natureza essencialmente empírica e que, normalmente, é muito difícil o professor se afastar dessa posição. O que acaba predominando é uma visão estratificada e isolada da educação, o que leva a uma prática pedagógica fundamentada, sobretudo, na repetição e na reprodução do conhecimento. As consequências dessa postura educacional são, no mínimo, extremamente inexpressivas para o aluno. Esse pensamento empírico refere-se tanto às ideias pedagógicas quanto à maneira de conceber a função educativa do saber que é o objeto de seu ensino.(MACHADO, S. D. A. et al. 2010, p. 20)
\end{abstract}

Mais uma vez retornamos à ideia de que as diferentes representações e visões de um mesmo objeto são indispensáveis para a verdadeira compreensão e boa formação de um conhecimento a partir de um saber provindo da noosfera. Tendo em mente que a visão mais estreita e repetitiva de um objeto matemático pode ser danosa para sua transposição para o aluno, nortearemos por estas vias a desenvoltura da abordagem ao problema inicial deste trabalho, da notação e sintaxe dos logaritmos.

É importante estar atento que a matemática existe em primeiro momento para compreender as relações que existem entre objetos de estudos, sejam eles números, funções, movimentos ou tantos outros. No decorrimento deste estudo, ela estimula a criatividade e a organização de um pensamento focado na resolução de problemas, sejam estes abstratos ou não. Quando nos prendemos demais à aplicação prática imediata, estamos deixando de lado boa parte da beleza da matemática que nos cativa e nos impulsiona em nossos estudos. Não podemos levar uma ferramenta matemática ao status do objeto matemático em si, não podemos encarar um binômio quadrado perfeito como sendo somente uma fórmula prémontada, pois é possível que $(a+b)^{2} \quad$ seja na realidade igual a $a^{2}+a b+b a+b^{2}$ devido a um espaço não comutativo, e essa visualização de um objeto matemático por vários ângulos é um sucesso escolar buscado pelo professor na sala de aula. A chamada desenvoltura da Matemática pela Matemática é parte do pesquisador desta área, que muitas vezes realiza descobertas que permanecem décadas sem uma utilização prática, mas nunca deixou de ser uma aplicação em potencial, um conhecimento matemático valioso e o produto do trabalho de um ser humano. 


\title{
Capítulo 2 - LOGARITMOS
}

\author{
Se não quiser perder tempo e esforço ao redescobrir coisa já sabida, deve antes \\ de tudo conhecer os pontos comuns dos pesquisadores precedentes, cujo ponto \\ de chegada deve servir para ele como ponto de partida. (LORIA, 1946)
}

A história da Matemática nos permite analisar o caminho que o conhecimento humano teve perante o passar do tempo, enxergar um elemento moderno com as lentes do passado nos permite uma nova maneira de conceber tal elemento, compreender as mudanças sofridas e possíveis ganhos ou perdas de significado que a inabalável passagem do tempo promove em tudo. Ao analisar a história dos logaritmos, buscaremos nesta seção e, de maneira cronológica, conhecer melhor sua concepção e justificativas do passado, entender as mudanças que este objeto sofreu até se tornar o dos tempos atuais e proporemos as mudanças que podem ser feitas de modo a facilitar sua compreensão e apreensão por parte dos alunos falantes de Língua Portuguesa do Brasil.

\subsection{LOGARITMOS NO PASSADO}

O termo "logaritmo" é associado com o escocês John Napier, nascido em 1550 na cidade de Edimburgo, não era um matemático profissional e também é reconhecido por ser um estudioso nos campos da física, astronomia, astrologia e teologia. Conhecido também pelo seu nome latino Ioannes Neper, ele viveu seus 67 anos permeado pelas novas descobertas, inovações e expansões das grandes navegações. Um dos problemas da época era a nova necessidade de lidar com muitos números de grandes proporções advindos das contas características da astronomia com seus números denominados astronômicos, estes extensos cálculos muitas vezes dificultavam em demasia o trabalho dos pesquisadores e estudiosos na busca do desenvolvimento humano sendo um pequeno erro durante uma multiplicação de dois números igualmente grandes poderia gerar um erro de proporções enormes no resultado final, que potencialmente pode seria propagado pelos cálculos subsequentes e inviabilizava completamente os resultados de um estudo. Na época, havia um método de transformar produtos em somas ao se utilizar de relações trigonométricas num processo conhecido como prostaférese, mas este processo possuía uma eficiência relativa, muitas vezes não poupando muito tempo perante os já enormes cálculos requeridos no desenvolvimento de uma ideia. 
Aos quarenta e quatro anos de idade, e propelido pelos estudos já publicados do monge alemão Michael Stifel, Napier evidenciou uma propriedade pertencente à duas progressões, uma geométrica e uma aritmética, em que o produto de termos de uma progressão geométrica (PG) se relaciona com a soma dos respectivos termos de uma progressão aritmética (PA) associada à primeira. Tomemos como exemplo as seguintes PA e PG:

Tabela 1 - PA e PG de Napier

\begin{tabular}{c|ccccccccccccc|}
\hline PA & 1 & 2 & 3 & 4 & 5 & 6 & 7 & 8 & 9 & 10 & 11 & 12 & 13 \\
\hline PG & 2 & 4 & 8 & 16 & 32 & 64 & 128 & 256 & 512 & 1024 & 2048 & 4096 & 8192 \\
\hline
\end{tabular}

Se desejamos efetuar a multiplicação de $32 \times 256$, o quinto e oitavo termos da PG de termo inicial 2 e razão 2 , podemos utilizar de uma outra visualização para estes números no sistema de representação das potências, e considerando então a operação $\quad 2^{5} \times 2^{8}$ e ao se utilizar da propriedade já conhecida na época da multiplicação de potências de mesma base, teríamos o resultado $2^{5} \times 2^{8}=2^{5+8}=2^{13}$ e $2^{13}=8192$. Se somarmos o quinto e oitavo termos da PA de termo inicial 1 e razão 1 , obteremos $5+8=13$, que é justamente a operação realizada nos expoentes da multiplicação dos termos da PG. Da mesma maneira, podemos efetuar outras multiplicações usando o mesmo raciocínio mas notando a propriedade: A multiplicação de dois dos termos da PG: $2^{a}, 2^{b}$, é relacionada a dois termos da PA: $a, b$, de modo que $2^{a} \times 2^{b}=2^{a+b}$, ou seja, ao invés de efetivamente multiplicar os dois números, por exemplo 64 e 16, podemos ver que estes números representam o sexto e quarto termos da PG e portanto são relacionados a 6 e 4 na PA, como $6+4=10$, temos que $64 \times 16=1024$ sem a necessidade de realizar os cálculos multiplicativos.

Mas este exemplo não resolve o problema dos cálculos enfrentado por Napier e seus contemporâneos, ao visto de que nem todos os números usados nos cálculos da época eram necessariamente escritos como potências de base dois usando expoentes inteiros, além de que quanto mais se avança na tabela da PA e da PG anterior, maior são os intervalos entre os números da PG, tornando difícil a multiplicação de 700 por 5000, por exemplo, já que ambos se encontram entre o décimo segundo e décimo terceiro termos das progressões. O que Napier fez para solucionar tal dilema foi alterar o termo inicial e a razão da PG para um número que gerasse intervalos menores, de modo a acessar o maior número possível de valores para que 
sua tabela fosse a mais completa possível. O número escolhido para a razão foi $0,9999999=\left(1-\frac{1}{10^{7}}\right)$, para evitar muitas casas decimais repetidas, multiplicava-se o número por $10^{7}$, e então Napier propôs a construção dessa tabela com os expoentes L necessários para que um determinado número $\mathrm{N}$ fosse obtido através da multiplicação de $\mathrm{L}$ vezes a razão por $10^{7}$, ou seja, $N=10^{7}\left(1-\frac{1}{10^{7}}\right)^{L}$. Este L foi chamado de razão (logos entre os números (aritmos) e daí nasce o termo logaritmo, o método desenvolvido que relaciona dois números através de uma PG, para que então se trabalhe com a PA corresponde aos expoentes, facilitando o trabalho dos matemáticos, astrônomos, físicos e muitos outros.

Na mesma época de Napier, com ideias correlatas, o matemático e relojoeiro suíço Joost Bürgi, nascido em 1552 em Lichsensteig, construiu o mesmo raciocínio, usando uma razão de $1,0001=\left(1+\frac{1}{10^{4}}\right)$ e um termo inicial de $10^{8}$, construiu uma tabela de mais de vinte mil termos e seus respectivos logaritmos. Muitas vezes é atribuído a ele a construção dos logaritmos, em especial por ter iniciado seus estudos seis anos antes de Napier, mas perde força nesta reivindicação por nunca ter publicado uma obra expondo estas ideias.

Em 1616, Napier é visitado em sua residência na sua cidade natal Edimburgo por Henry Briggs, um matemático inglês nascido em 1561, onde discutiram sobre as ideias e adaptações para os logaritmos que mostravam um potencial enorme, mas, ainda assim, necessitavam de alguns ajustes em especial na escolha do termo inicial e razão da PG que os representava, já que os logaritmos propostos inicialmente por Napier se baseavam no, aparentemente arbitrário, número dez milhões e numa razão muito próxima do número um. Ao retornar de uma segunda visita à Napier em 1617, Briggs publica os primeiros mil Logaritmos Briggsianos relativos aos números naturais menores que mil, onde nesta nova tabela de logaritmos, tanto o termo inicial quanto a razão eram o número dez, conceito que persiste até os dias atuais como a primeira forma com que os estudantes têm contato quando se deparam com o estudo dos logaritmos: os logaritmos decimais, ou logaritmos comuns. Segundo Howard Eves (2004, p. 246, 346) "Napier e Briggs concordaram que as tábuas seriam mais úteis se fossem alteradas de modo que o logaritmo de 1 fosse 0 e o logaritmo de 10 fosse uma potência conveniente de 10, nascendo assim os logaritmos briggsianos ou 
comuns".

A notação atual para os logaritmos em que $\log _{a} b=c$ representa $a^{c}=b$ é mais uma das vastas contribuições do matemático e físico suíço Leonhard Paul Euler, nascido em 1707 na cidade de Basileia, considerado um dos maiores matemáticos de todos os tempos que ao menos para os logaritmos não só simplificou a notação quanto também definiu logaritmos para números negativos e complexos, aumentando as possibilidades de uso destas poderosas ferramentas (MAOR, 1994). Um exemplo notável das contribuições deste célebre matemático é a Fórmula de Euler que relaciona funções trigonométricas com a função exponencial garantindo que para qualquer número real $\phi$ em radianos, temos que:

$$
e^{i \phi}=\cos \phi+i \operatorname{sen} \phi
$$

E em especial, quando $\phi=\pi$ temos a chamada "a fórmula mais notável em matemática" (FEYNMAN, Richard,1970, p10) devido aos seus usos ímpares de noções de adição, igualdade, multiplicação e exponenciação e de cinco constantes fundamentais da matemática: $0,1, \mathrm{i}, \mathrm{e}, \pi$.

$$
e^{i \pi}+1=0
$$

Euler é aclamado até os dias de hoje por suas pesquisas e contribuições em diversas áreas da matemática, tem a constante $e$ nomeada em sua homenagem, constante essa a base dos logaritmos neperianos, é chamada de Número de Euler.

Na notação de Euler, temos que "o número que relaciona a base a com o logaritmando b é o logaritmo c" se e somente se "a base a elevada ao logaritmo c equivale ao logaritmando b", ou como escrito na sentença mais enxuta, $\log _{a} b=c \Leftrightarrow a^{c}=b$. Esta notação é a usual até os dias de hoje e, como regra de conformidade, se a base do logaritmo for 10 , ou seja, se estivermos tratando dos logaritmos briggsianos, simplesmente omitiremos a base e escreveremos como no exemplo: $\log 100=2$. Outro logaritmo em que há uma regra especial é o de base $e$, o chamado número de Euler, em que os logaritmos da forma $\log _{e}$ em homenagem a Napier (cujo nome em latim é Ioannes Neper) são chamados de logaritmos neperianos, ou logaritmos naturais e se utilizam da notação $\ln$.

Temos então que os logaritmos foram concebidos como uma ferramenta de cálculo, sem uma preocupação muito grande com seu contexto e relações com outros objetos matemáticos, incluindo a própria exponencial, em que só foram firmemente ligadas em 
décadas posteriores à implementação dos logaritmos como ferramenta, quase que como uma construção didática mas focada em sua aplicação prática. As ligações entre os logaritmos e as exponenciais são muito mais firmes do que uma mera bijeção entre suas características, temos que o logaritmo e a exponencial são operações inversas tais como a adição e a subtração, um fato que aumenta a força desse objeto matemático e abre ainda mais as possibilidades de seu uso, mesmo que este não tenha sido o propósito inicial de seu desenvolvimento como objeto de estudo da matemática.

\subsection{LOGARITMOS NO PRESENTE}

Desde o advento da calculadora e dos computadores, as contas extensivas deixam de ser um problema constante na vida do cientista, pesquisador e trabalhador, que agora pode fazer com que estas máquinas poderosas realizem o "trabalho manual" de efetuar as diversas operações necessárias de seu dia a dia: independente de quão extensas forem as operações, os computadores são capazes de realizar milhares delas por segundo, fazendo com que as ferramentas capazes de transformar produtos em somas a partir do uso de logaritmos pré calculados e tabelados se torne desnecessário. Isso não quer dizer que os logaritmos se tornaram obsoletos, pelo contrário, desde sua concepção, muitos outros significados foram atribuídos e desenvolvidos devido ao estudo dos logaritmos como algo além de uma ferramenta de cálculo.

Um dos pontos-chave do desenvolvimento dos logaritmos como um poderoso objeto matemático vem da conexão de que os logaritmos possuem com a exponenciação: serem funções inversas, ou seja, para valores reais $\mathrm{a}, \mathrm{b}$ e c, sendo $a \neq 1, a>0$ tal que $a^{c}=b$, temos que $\log _{a} b=c$. Analisando ambas como funções $f(x)=a^{x}, g(x)=\log _{a} x$ temos que

$$
\begin{gathered}
(1) f o g(x)=f(g(x))=a^{\log _{a} x}=x \\
\mathrm{e} \\
(2) g o f(x)=g(f(x))=\log _{a} a^{x} \\
\log _{a} a^{x}=x \cdot \log _{a} a=x \cdot 1=x
\end{gathered}
$$

E como $f \circ g(x)=g o f(x)=x$, em outras palavras, a composição de ambas 
independente da ordem é a função identidade, chama-se $f$ e $g$ de funções inversas de modo que tomando-se um elemento $\mathrm{x}$ do domínio de f, e aplicando-o na função $\mathrm{f}$, chega-se no valor $f(x)=y$, aplicando-se então este valor y na função $g$, temos $g(y)=x$ de modo que a função g "desfaz" a operação feita pela função $f$.

Isto quer dizer que as sentenças $a^{c}=b \Leftrightarrow \log _{a} b=c$ são sentenças equivalentes $\mathrm{e}$ possuem o mesmo significado, mesmo possuindo significantes diferentes. Frases como "a elevado a c é b" e "c é o número que elevamos a para obter b" parecem então estar relacionadas da mesma maneira que "o homem pegou o chapéu" e "o chapéu foi pego pelo homem", ou seja, uma inversão do sujeito e do objeto da frase, os objetos da oração, mas com o mesmo resultado final, seja o cálculo ou a ação de pegar o chapéu.

Em questão de usos, os logaritmos são encontrados, portanto, em praticamente todo momento que se tem uma exponenciação, sendo alguns exemplos notáveis:

- Escala Richter, usada para medição da magnitude de abalos sísmicos pelo mundo, obtida através do logaritmo de base 10 da amplitude das ondas obtidas por sismógrafos, ou seja, um terremoto considerado de magnitude 3 na escala Richter é 10 vezes menos intenso que um de magnitude 4. (ELLSWORTH, p. 177, 2008)

- $\quad \mathrm{Na}$ análise de ondas sonoras, utiliza-se muito a unidade decibel (dB) que nada mais é do que o logaritmo do quociente da intensidade medida com relação a uma intensidade referencial: $\quad I_{d B}=10 \log \left(\frac{I}{I_{0}}\right)$, sendo $I_{d B}$ a intensidade em decibels, $I, I_{0}$ respectivamente a intensidade medida e a intensidade acústica de referência $I_{0}=10^{-12} \mathrm{~W} / \mathrm{m}^{2}$ segundo o dicionário de termos padrão do Institute of Electrical and Electronics Engineers (IEEE) em 2000.

- No estudo das progressões geométricas, as sequências obtidas através do produto de uma constante por uma razão um determinado número de vezes. Costuma-se denominar o termo geral de uma PG por $a_{n}=a_{1} \cdot q^{n-1}$, mas raramente se explicita o fato de que: 


$$
\begin{gathered}
\log a_{n}=\log \left(a_{1} \cdot q^{n-1}\right) \\
\Rightarrow \log a_{n}=\log a_{1}+\log q^{n-1} \\
\Rightarrow \log a_{n}-\log a_{1}=(n-1) \log q \\
\Rightarrow(n-1) \log q=\log \frac{a_{n}}{a_{1}} \\
\Rightarrow n=\frac{\log \frac{a_{n}}{a_{1}}}{\log q}+1
\end{gathered}
$$

Ou seja, podemos obter o número do termo da PG a partir de uma relação entre logaritmos dos termos $a_{n}, a_{1}$ e $q$, isto pode não parecer tão usual, mas é uma questão comum de se tratar quando o assunto da aula são os juros compostos, que nada mais são do que uma PG, sendo que o número de meses/anos em que os juros são aplicados podem muito bem ser a incógnita a ser calculada.

- Juros compostos, como mencionado no item anterior, apesar de não serem nada além de uma PG, normalmente são tratados como um conteúdo separado, mais próximo da economia do que da matemática abstrata, em que há repetidas multiplicações de um termo inicial por uma taxa (de juros) durante um certo número de intervalos de tempo (meses/anos).

- Taxas de crescimento exponencial, geralmente associadas a microrganismos que se multiplicam por divisão celular, na microbiologia a curva de crescimento microbiano ideal (isolado completamente) possui diversas fases, a segunda em que há a maior atividade celular e a taxa de crescimento se torna constante é a fase exponencial, ou fase log. Ainda há outros padrões de crescimento destes microrganismos como a fase constante, ou estacionária, e ainda mesmo uma fase de declínio, ou morte.

Mas infelizmente, os logaritmos, mesmo possuindo uma multiplicidade de usos na ciência moderna, sofreram um processo similar ao dos binômios quadrados perfeitos, onde pouco se entende sobre o que a ferramenta significa, rege-se a utilização de fórmulas e raciocínios de repetição, com uma linguagem pouco significativa para o aluno e muito algoritmizada. Por experiência pessoal, o conceito dos logaritmos é um estigma na matemática: é muito mais comum encontrar pessoas que desgostam deste importante objeto matemático do que as que compreendem e o apreciam. Um dos possíveis motivos para esta aversão aos logaritmos pode ser a distância incomum que a linguagem utilizada está do usuário. A notação comum utilizada pelos logaritmos é a de que $\log _{a} b=c$, ou seja 


\section{O logaritmo de b na base a é igual a $c$.}

Se analisarmos esta sentença em partes, temos que o sujeito da oração é o logaritmo de $b$, este por sua vez possui o adjetivo na base $a$, que adiciona uma qualidade específica ao mesmo. Nosso sujeito é ligado por um verbo de ligação é ao objeto, no caso o "resultado" da operação, $c$, por uma relação de igualdade. A ordem portanto neste caso é SVO como de costume em nossa Língua Materna. Os logaritmos são normalmente um conceito abordado como extensão dos exponenciais, muito frequentemente vistos lado a lado, explicitando as semelhanças entre as propriedades e axiomas definidos para os dois e como eles se relacionam. Vamos portanto analisar em conjunto as sentenças equivalentes $\quad \log _{a} b=c \quad \mathrm{e}$ $a^{c}=b . \quad$ Esta última pode ser lida como

\section{O número a elevado ao expoente c é igual a $b$.}

Desta vez temos que nosso sujeito, o número $a$, ao ser especificamente elevado a $c$, o adjetivo desta sentença, é novamente unido pelo verbo de ligação é ao "resultado" da operação $b$, por uma relação de igualdade. Novamente estamos perante uma frase na ordem SVO.

Agora vamos analisar as funções sintáticas a qual estamos interpretando cada uma das variáveis em cada situação:

Tabela 2 - Relação sujeito verbo objeto Log x Exp

\begin{tabular}{|c|c|c|c|}
\hline & Sujeito & Adjetivo & Objeto \\
\hline Logaritmo & $\mathrm{b}$ & $\mathrm{a}$ & $\mathrm{c}$ \\
\hline Exponencial & $\mathrm{a}$ & $\mathrm{c}$ & $\mathrm{b}$ \\
\hline
\end{tabular}

Ao se ler a sentença na forma de logaritmo e de exponencial, os sujeitos, adjetivos e objetos trocam de posição, por consequência, as frases $\log _{a} b=c \quad$ e $\quad a^{c}=b$ que passam a mesma ideia, possuem uma ordem diferente uma da outra. Algo muito similar ocorre no português é a chamada voz passiva, vejamos portanto as sentenças

\section{Alvo pegou a maleta.}

\section{A maleta foi pega por Alvo.}

Onde a ordem do sujeito e objeto estão invertidas como no caso do logaritmo e da exponencial. Mas há uma diferença entre os dois casos: Alvo e a maleta estão unidos por uma 
ação (pegar / ser pega) que é unilateral: o que exerce a ação e o que a ação é exercida em são os mesmos nas duas situações, e isto não ocorre no caso das sentenças matemáticas, onde não há uma ação mas sim uma ligação por uma relação de igualdade. Não podemos então entender o caso do logaritmo e da exponencial como uma mera inversão de sujeito e objeto e devemos ser cautelosos com as análises dos verbos já que o maior representante deste grupo sintático na matemática são os de ligação, presente na relação de ser igual. Ainda assim, mesmo não sendo um caso de voz passiva e uma oração em que não há um sujeito aplicando uma açao em um objeto, a impregnação da Matemática pela Língua Materna se mostra mais uma vez um ponto crucial de se considerar: o modo como se escrevem e ordenam as duas sentenças que são equivalentes, o logaritmo e a exponencial, é muito diferente, dificultando a verdadeira união dos dois objetos matemáticos na transposição do saber matemático para o conhecimento próprio do aluno: este precisa se apropriar constantemente das propriedades operativas de logaritmo e exponencial para tentar compreender os cálculos a que é apresentado e isto exige tempo e capacidade de processamento mental, diminuindo a ligação que deveria ser tão mais clara entre a exponenciação e a razão com que se exponencia números (logos aritmo).

Tendo em vista este problema, buscamos então uma possível abordagem para o dilema da dificuldade excessiva de aprendizagem do objeto matemático dos logaritmos. Acreditamos que a notação utilizada não é apropriada, ao menos para a população brasileira, por se tratar de um significante (símbolos e notação) muito distante de seu verdadeiro significado, tornando a apropriação destes conhecimentos pouco significativas. Esta abordagem será apresentada e discutida a seguir, incluindo as motivações, particularidades e dificuldades que foram encontradas em seu desenvolvimento.

\subsection{LOGARITMOS NO FUTURO}

Nas duas últimas seções deste capítulo analisamos as origens dos logaritmos, e o decorrer de sua história como objeto de ensino, pesquisa e cálculo, além de alguns dos seus usos atuais, tanto em questão de aplicação quanto em motivação para que este objeto matemático faça parte do currículo atual da Escola Básica brasileira. Seguindo a ideia de percorrer a história e o passado dos logaritmos e a maneira como estes se posicionam na vida escolar e no ambiente de pesquisas e aplicações, trataremos agora de algumas possibilidades para seu futuro. Não estamos de maneira alguma determinando este futuro, mas sim deixando 
à tona algumas possibilidades que podem alterar o curso atual dos logaritmos, que possam ser menos um dos estigmas da Matemática para a população geral e mais um conhecimento para ser refinado no saber de cada indivíduo. Para que este objeto perdure tanto em significado quanto em significante, será necessário rever o modo como abordamos esta tão importante área da Matemática, agora considerando também suas relações e impregnações com a Língua Materna de uma forma mais mutualística ou ao menos comensalística.

De acordo com a Assessoria de Comunicação Social (2016)

Logaritmo - A especificidade da área exige reflexão que aponte para a integração da matéria nas diferentes etapas da vida escolar, além de gestão compartilhada de conhecimento. "Muitas vezes aprendemos uma operação matemática sem nos darmos conta de que estamos aprendendo uma linguagem", observa o professor Luiz Carlos Menezes, da Universidade de São Paulo (USP).

Além de compreender o conceito matemático dos logaritmos, deveríamos poder ter um contato com eles em momentos diferentes da vida escolar além da função de "função inversa da exponencial". Os logaritmos são a razão (logos) entre números (aritmos) e antes de qualquer tipo de utilização prática, representação de maneira gráfica ou representação na forma de função, os logaritmos representavam qual era a quantidade que se utiliza como expoente para que uma base se torne um determinado resultado. Se $2^{3}=8$ é porque a razão numérica que relaciona o número dois com o número oito é o número três, este último pode ser escrito como o logaritmo que leva a base dois ao número oito $\left(\log _{2} 8=3\right)$ e também significa que devemos multiplicar a base dois por ela mesma três vezes para alcançar o resultado oito. Esta última leitura não exige um embasamento teórico aprofundado e é uma atividade possível de ser aplicada tão cedo o aluno se encontra capaz de multiplicar um número por ele mesmo. Claro que uma maior significância de uma atividade como esta deve ser considerada com cautela, mas o ponto em questão é que a pergunta pode ser feita e portanto a apresentação desta linguagem (multiplicar um número por si mesmo um certo número de vezes) começa a sedimentar-se como uma "aplicação em potencial", uma “operação possível”, uma "opção de cálculo", ou seja, podemos introduzir o conceito de logaritmo muito antes da criança sequer conhecer a palavra logaritmo ou mesmo a exponenciação. Mesmo que esta operação seja inicialmente baseada na repetição, ela ainda trará algum significado para o aluno, e não seria o único objeto matemático que o aluno inicialmente conhece de uma maneira baseada em exemplos repetidos e/ou metódicos.

Se então não é o significado dos logaritmos a maior barreira que encontramos, haja 
vista que este pode ser abordado em múltiplos níveis educativos e está muito próximo do significado da exponenciação, que normalmente não gera os níveis de asco que são encontrados numa aula de logaritmos, na resolução de exercícios de tópicos diferentes que necessitem deste objeto ou na opinião pessoal de muitos cidadãos. Acreditamos que uma das maiores dificuldades encontradas na aprendizagem dos logaritmos é o seu significante, ou seja, a forma como é representado. Baseando-se em todos os conhecimentos abordados até agora, sejam eles de transposição didática, gramática gerativa, ordem dos elementos numa oração, regras de conformidade já estabelecidas, quebras de paradigma, logaritmos e suas relações com exponenciais e outras áreas do conhecimento humano, e a impregnação entre a Matemática e a Língua Materna; acreditamos que os maiores causadores de atrito na boa aceitação dos logaritmos são:

- os símbolos que os representam

- a posição em que estes símbolos estão

- a palavra que nos referimos a este objeto

- a leitura da sentença a partir da Língua Materna

Vamos agora inicialmente analisar cada um destes tópicos para melhor explicitar o pensamento em que nos baseamos para colocá-los em evidência.

\subsubsection{Símbolos e palavra}

Em relação aos símbolos que representam o objeto matemático dos logaritmos, estamos nos referindo aos signos que compões a representação que fazemos dele, ou seja, o significante que significa este significado. A notação atual, como já comentamos, é a mesma há quase três séculos, desde que foi proposta por Euler e ela relaciona os três elementos principais do logaritmo: o logaritmando, a base e o logaritmo;

Figura 3 - O Logaritmo

\section{LOg Logaritmando $=$ Logaritmo} Base

O ponto em que esta notação falha é justamente em ser uma maneira simples e concisa 
de representar o objeto, unimos os símbolos e palavra que o representam nesta seção justamente porque os símbolos ( $\log , \mathrm{Ln}$ ) derivam-se da própria palavra logaritmo. A proporção (logos) entre números (aritmos) não é um conceito que dá, de maneira clara e logo de início, a ideia que queremos representar aos estudantes. O logaritmo pode, com certeza, ser compreendido como a razão que se eleva um número para que se resulte num outro, mas o ponto em questão é que há uma palavra que o representa de maneira muito mais significativa com a maneira como ele é abordado na Escola Básica: a palavra expoente. Por ser tão ligado à exponencial, seja em aplicações, função, construção e significado, o logaritmo também pode ser entendido como "o expoente em que se eleva um número para que se resulte num outro", nesta sentença, que é equivalente à utilizada normalmente em questão de significado, estamos somente propondo a alteração da palavra logaritmo pela palavra expoente. Acreditamos que, sendo que a palavra logaritmo não é tão significativa para o aluno por ser um significante introduzido num momento posterior à definição do expoente e da exponenciação, para então ser ligado a ambos e se preencher de significado, e esta palavra já carrega um histórico de asco por parte da população, nada temos a ganhar com seu uso. É de suma importância compreender que não alterar-se-á nem um ponto do significado dos logaritmos, todas as propriedades, usos, importância e funções convencionais em nada se alterarão além da maneira como escrevemos este objeto matemático.

Se então estamos substituindo a palavra logaritmo pela palavra expoente, como ficariam as representações de logaritmos e logaritmos naturais? Algumas proposições são as seguintes:

Figura 4 - Proposições para a notação (escrita)

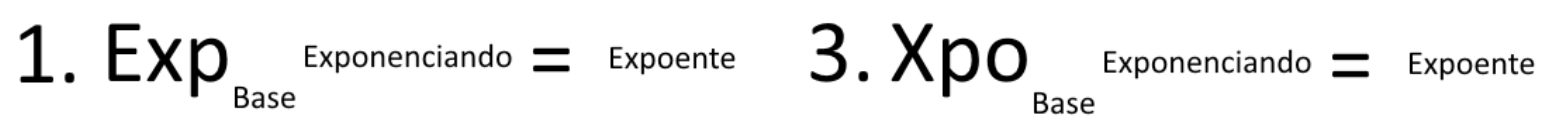

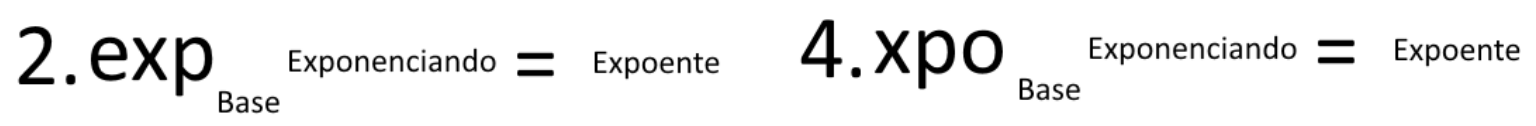

A proposição número um é a equivalência da notação atual de logaritmos, ou seja, as três primeiras letras da palavra que representa o objeto matemático. Como estamos propondo a troca do nome do objeto para expoente, trocaríamos também as letras "Log" pelas letras "Exp". A proposição número dois possui a mesma justificativa que a número um, mas difere na utilização exclusiva de letras minúsculas, já que é comum que se escreva "log" e não "Log" 
na notação atual. A proposição quatro possui a mesma ideia das anteriores de alterar a escrita do significante para melhor representar o significado, mas esta atua mais com a sonoridade do que com a escrita, utilizando-se somente as letras "exp" estaríamos rompendo a palavra expoente em seus fonemas iniciais de maneira inadequada, pois a escrita expoente não comporta toda a grafia das duas primeiras sílabas da palavra expoente. Claramente as letras xpo também não comportam toda a grafia das duas primeiras sílabas da palavra em questão, ex e po, mas estamos utilizando o som da letra $x$ para expressar a sonoridade da sílaba $e x$, como que num pronunciamento silencioso da letra $e$ e mantendo a sílaba po por completo, dessa maneira nos aproximamos mais do som das sílabas ex-po do que nas representações anteriores apesar de nos distanciarmos um pouco da forma de escrita que é relativamente mais bem representada nas outras duas. A proposição quatro tem a mesma relação com a número três que a dois possui com a um, só utilizando letras minúsculas de maneira a alterar o mínimo possível da grafia atual dos logaritmos. Podemos tratar as primeiras duas proposições como um foco maior na escrita do expoente e as proposições três e quatro como um maior foco no som da palavra expoente.

Nas quatro proposições, o logaritmando e logaritmos são substituídos por exponenciando e expoente, respectivamente, para maior concordância com esta maneira alternativa de representar os logaritmos: como expoentes em vez de como a razão entre dois números.

A motivação para esta troca quase que somente num nível vocativo do objeto matemático vem da impregnação que a Língua Materna possui na Matemática e da preocupação com uma maneira de representar os logaritmos de uma maneira mais objetiva. Pelas ideias propostas por Machado quando diz

\footnotetext{
Assim, se no ensino da Língua Materna a fala é o natural suporte de significações para inflar os balões dos signos escritos, funcionando como um degrau intermediário na passagem do pensamento à escrita, no caso do ensino da Matemática a inexistência de uma oralidade própria não possibilita alternativas senão as seguintes: circunscrevê-lo aos limites da aprendizagem de uma expressão escrita, abdicando-se da expressão oral, o que parece tão natural quanto abdicar do uso das pernas para caminhar; ou então fazê-lo comungar decisivamente com a Língua Materna, compartindo sua oralidade e, em decorrência, impregnando-se dela de uma forma essencial. (MACHADO, 2011, p.114)
}

E se a fala, uma parte da Língua Materna, impregna de forma essencial e funciona como uma passagem obrigatória do pensamento à escrita, além de encher de significado os signos escritos, quando o mesmo deve ser aplicado à Matemática, percebemos que descartar 
totalmente a oralidade compartilhada pela Língua Materna é inviável, o caminho a ser tomado é o de considerar as particularidades e atuar de modo conjunto com a Língua Materna. A notação atual para logaritmos não possui esta consideração em questão e por consequência não possui seu "balão" de significado totalmente "inflado" de modo que apresenta uma barreira adicional que dificulta a transposição do conhecimento a um saber pessoal de cada indivíduo. Não estamos alterando a função do objeto matemático dos logaritmos que será apresentada ao estudante e a maneira de abordar este conhecimento, seja em apresentação das propriedades ou exercícios, que por sua vez podem ser facilmente reescritos usando esta notação alternativa, mas estamos alterando os logaritmos de uma maneira conceitual, estamos aproximando este objeto dos estudantes ao usar de uma linguagem que é mais significativa, haja vista que os expoentes são um objeto da Matemática com maior sucesso escolar que os logaritmos, ao ponto de que eles se tornam normalmente o uma região de ancoramento para muitos alunos: estudantes que compreendem os logaritmos praticamente por bijeções com as exponenciais, trocando as sentenças $\log _{a} b=c$ por $a^{c}=b$ sempre que possível, utilizando-se da propriedade $a^{c} \cdot a^{d}=a^{c+d}$ ao invés da $\log _{a} b \cdot c=\log _{a} b+\log _{a} c$ mesmo que esta última seja mais prática na situação em questão.

Mas não é somente alterando a forma de escrita dos logaritmos que estaremos tornando-os tão significativos quanto podemos, há ainda uma segunda barreira que tentaremos contornar para melhor representar este objeto matemático.

\subsubsection{Posição e leitura}

Se na seção anterior nos preocupamos com a forma de escrita e fala dos logaritmos, agora estamos colocando em questão a maneira como se concatenam os símbolos utilizados em sua representação.

Relembremos que a ordem dos objetos na exponenciação e na logaritmação se dá, respectivamente, nas formas:

O número a elevado ao expoente c é igual a $b . \quad\left(a^{c}=b\right)$

O logaritmo de b na base a é igual a $c . \quad\left(\log _{a} b=c\right)$

Em especial, tome nota da ordem com que tomamos cada elemento, representada pela 
seta na figura a seguir:

Figura 5 - Ordem na notação atual
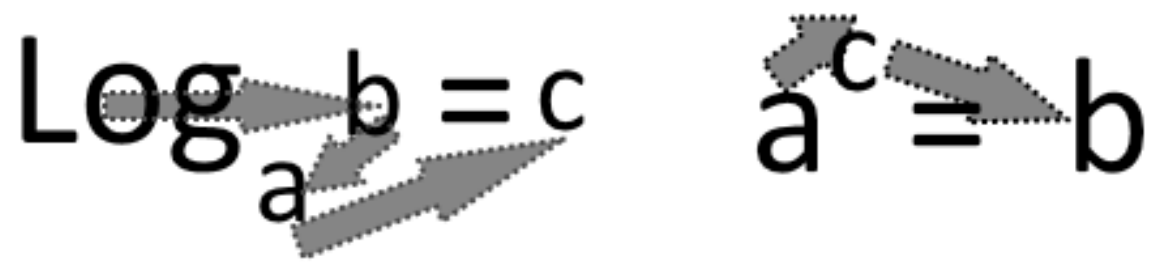

Percebamos que a notação para exponencial é mais linear e direta em sua ordem de ler os signos: da esquerda para a direita como na Língua Materna e claramente pode-se identificar a sentença em português que se relaciona diretamente com a sentença em linguagem matemática. Já a notação para logaritmo possui um "zigue-zague" em seu meio, alterando a fluência da leitura com duas súbitas e inesperadas mudanças de sentido, isso causa como que um freio para a linearidade da leitura da expressão. Um exemplo clássico onde há uma quebra de leitura, e consequentemente uma exigência de maior tempo para compreender a sentença escrita, vem da primeira parte da famosa letra do poema de Joaquim Osório Duque Estrada, onde ele recita:

Ouviram do Ipiranga as margens plácidas

De um povo heroico o brado retumbante,

E, quando colocamos estas sentenças na ordem "correta" de leitura, temos o seguinte:

As margens plácidas do Ipiranga ouviram

o brado retumbante de um povo heroico

E então podemos compreender na verdade quem pratica a ação e qual é a ação que é praticada. Esta segunda forma não é a presente no poema e na letra em vigor do Hino Nacional Brasileiro justamente por não ter o ritmo e sonoridade desejadas pelo poeta, que se utiliza da licença poética para alterar a forma das frases de modo a obter o efeito mais melódico que é então encontrado em nosso hino. Mas os logaritmos não são um hino, e não é possível se valer da licença poética neste caso, estamos tratando de finalidades diferentes e deveríamos tentar ao máximo manter a ordem usual de leitura do português, SVO (Sujeito - 
Verbo - Objeto) para facilitar o deslocamento da informação pelas linguagens duplamente embrenhadas: Matemática e Língua Materna.

Então, assim como a mudança na escrita dos logaritmos proposta anteriormente, e já considerando a nova "função expoente" como sendo o signo usual para representar os logaritmos, vamos analisar estas proposições para uma nova ordem de leitura e posição dos termos da sentença atualmente escrita como $\log _{a} b=c$. Utilizaremos a proposta número dois para a forma de escrita como exemplo para evitar exemplos repetitivos mas consideraremos todas as quatro como potenciais representações de escrita, lembrando que o foco no momento é a posição e ordem de leitura dos logaritmos.

Figura 6 - Proposições para a notação (posição)

\section{1. $\exp (a ; b)=c \quad 3 \cdot \exp a ; b=c$ 2. $\exp (a \rightarrow b)=c \quad 4 \cdot \exp a \rightarrow b=c$}

As quatro propostas trazem uma maior linearidade na leitura, da esquerda para a direta temos a representação em linguagem matemática da sentença

\section{O expoente que faz a se tornar béc.}

Que nada mais é do que uma releitura da expressão já contida na leitura do logaritmo usual, mas evitando redirecionamentos e a presença de elementos subscritos, como é o caso da base do logaritmo atual. A primeira proposição traz a base e o logaritmando separados por ponto e vírgula, mas tal representação pode assemelhar-se muito com um par ordenado, o que não é desejado por poder ser um ponto de confusão dos dois objetos, mas pode ser uma aliada na configuração da expressão do logaritmo. A segunda proposição insere uma seta como indicadora da "transformação" que será exercida pelo expoente, dando uma ideia de movimento além de atuar como separador da base e do logaritmando. As proposições três e quatro são respectivamente as proposições um e dois mas sem o uso dos parênteses, numa tentativa de evitar a confusão entre esta notação e a de par ordenado. 


\subsubsection{Expoente}

A construção de qualquer sistema de representação envolve um processo de diferenciação dos elementos e relações reconhecidas no objeto a ser apresentado e uma seleção daqueles elementos e relações que serão retidos na representação (FERREIRO, 1986, p.10)

Ao se utilizar de uma nova notação, estamos não só alterando a parte visual da representação do objeto matemático em questão, mas sim observando o conhecimento em questão por um ângulo novo, buscando uma focalização que seja mais significativa para o público-alvo em questão: os alunos falantes de Língua Portuguesa de nosso país. Como já foi discutido, segundo as ideias de Duval, uma representação semiótica precisa ao mesmo tempo representar parte das características do objeto e não representar outra parte das características do objeto. Além disso devemos abrir um caminho para que este conceito seja analisado por mais de um ângulo, de modo a permitir a tradução dessa representação em outras, já que a apreensão de conhecimento em forma de saber de um aluno não pode prescindir de uma multiplicidade de pontos de vista, ou seja, não há noésis sem semiósis.

Ao tratar o logaritmo como expoente, poderemos ter uma aproximação maior entre este objeto e a exponencial, estamos propondo portanto uma notação de logaritmo que não só procura linearizar mais o raciocínio e facilitar a linguagem mas também representar o logaritmo de uma maneira ligeiramente diferente da razão entre dois números, tentamos com esta outra notação passar a ideia principal de que o logaritmo, que podemos chamar então de expoente, se trata do expoente que leva um número em outro, uma maneira de representação que acreditamos ser mais próxima da exponencial e que possibilita uma melhor construção de um saber significativo a partir deste conhecimento específico.

Nossa inclinação para esta abordagem vem dos estudos de Duval, onde este revela que

[...] numerosas observações em aula, assim como a análise dos resultados de investigações e de avaliações, e experiências de aprendizagem mostram que $a$ conversão das representações semióticas constitui a atividade cognitiva menos espontânea e mais difícil de adquirir para a grande maioria dos alunos. Não somente a mudança de registros levanta obstáculos que são independentes da complexidade do campo conceitual no qual se trabalha, mas, além disso, a ausência de coordenação entre diferentes registros cria muito frequentemente uma deficiência para as aprendizagens conceituais. Inversamente, uma 
aprendizagem especificamente centrada na mudança e na coordenação entre diferentes registros de representação produz efeitos espetaculares nas macrotarefas de produção e de compreensão (DUVAL, 2009, p. 63).

Ou seja, como muitos alunos não desenvolvem e/ou refinam a capacidade de observar um mesmo objeto matemático por múltiplos ângulos, através de um leque de representações do mesmo, estes jovens criam uma deficiência para aprendizagens de outros conceitos, tendo em vista que muitos tópicos de matemática são ferramentas para compreensão de tópicos futuros; enquanto aqueles que melhor desenvolvem a capacidade de transitar entre representações de um mesmo objeto, tendo uma visão mais completa do mesmo, devido a aulas voltadas para a maturação dessa habilidade, se mostram mais preparados para as aulas seguintes e desafios que virão.

Ao colocarmos as exponenciais e os expoentes lado a lado e utilizarmos de uma notação mais clara e concisa, que leve em consideração a Língua Materna de seus usuários, estamos buscando que estes tenham menos dificuldades em compreender o objeto matemático e seu significado, que exista um menor número de passagens de tradução entre linguagens e um maior número de possibilidades de tradução entre sistemas de representação, que segundo Duval é parte necessária da apreensão de conhecimento na forma de saber pessoal. Estamos focalizando a experiência de aprendizagem dos logaritmos por um ângulo que leva mais em conta "quem é o expoente que transforma um número em outro" ao invés da maneira usual de se compreender este objeto matemático como "a razão numérica entre dois números", acreditamos que essa maneira de se posicionar para com o conhecimento propicia uma maior significação por parte dos alunos, pois a moldura lógica que o pensamento ocidental segue é baseada, como dito pelo filósofo chinês Chang Tung-Sun, em substância e atributo. Ao deixar clara a ideia de que nosso objeto é um expoente que tem a propriedade de levar um número a em um número $b$, estamos nos utilizando de uma linguagem que acreditamos ser mais clara do que a de dizer o logaritmo que tem a propriedade de ser de $b$ na base $a$, uma forma escrita onde implicitamente representa-se o mesmo objeto, mas por uma maneira mais próxima da nossa organização de pensamento, que atribui qualidades a sujeitos, que se ordena de maneira linear e contida numa linha, da esquerda para a direita.

Tendo em vista as propriedades que acreditamos serem facilitadoras na apreensão do conhecimento dos logaritmos como um saber, considerando as particularidades das proposições de notação discutidas anteriormente, vamos representar o expoente c que leva o número a no número $b$ como sendo: 


$$
x \text { pо } a \rightarrow b=c
$$

- Utilizando as letras xpo para representar o expoente, estamos dando ao mesmo tempo um foco na sonoridade da expressão, a sílaba tônica da palavra expoente é diferente da palavra exponencial, e evitando a possibilidade da confusão da exponenciação com o expoente, já que exp é utilizado em algumas linguagens computacionais como sendo a função exponencial de base e, ou seja, $\exp (x)=e^{x}$;

- A letra inicial da notação ser maiúscula ou minúscula não causa nenhuma diferença que não estética. Escolhemos mantê-la minúscula para manter o padrão já existente nos logaritmos que são escritos geralmente como log e não Log;

- A seta direcional tem a função dupla de dar a ideia de movimento, de "transformação" de um número em outro pela ação do expoente e de separar a base do logaritmando, que poderia ser representado pela palavra exponenciando para melhor adequação desta notação;

- A ausência de parênteses se dá tanto pelo fato de que nos logaritmos já não há esta necessidade, nem possibilidade, de representar a base e o logaritmando entre parêntesis, mesmo o somente o próprio logaritmando estar entre parênteses nao é uma notação muito comum, e também deseja-se ao máximo evitar a confusão da base e do exponenciando com um par ordenado, confusão esta que poderia denegrir a clareza que estamos buscando com esta nova representação.

Esta escolha de notação considera a maneira de expor o conhecimento aos alunos, mas a internalização dos saberes, segundo Luiz Carlos Paes, ocorre de maneira singular na transposição didática do conhecimento para cada um dos alunos. Não podemos afirmar com certeza de que esta forma será a mais aceita pelos alunos, e uma análise de sua viabilidade como instrumento didático exigiria muito tempo, seria interessante realizar:

- Uma abordagem de "expoentes" numa turma ao mesmo tempo que se utiliza a de logaritmos em outra sala de mesmo ano (ou dividir uma mesma sala em duas menores para esta atividade);

- Uma exposição continuada para uma turma mais jovem, para se introduzir perguntas como "Qual expoente se usa em 3 para alcançar 27?” nos raciocínios presentes nos primeiros contatos com a potenciação, a fim de embasar desde cedo a exponencial 
como uma sentença válida como operação. A Base Nacional Comum Curricular apresenta como objeto de conhecimento as "Operações (adição, subtração, multiplicação, divisão e potenciação) com números naturais" no $6^{\circ}$ ano (BRASIL, 2017, p. 298, grifo nosso), portanto poderíamos já realizar em turmas dessa escolaridade um embasamento para os conceitos que serão propostos no futuro, inclusive analisar efetivamente o desenvolvimento destes alunos nos anos seguintes para validar a possível eficiência desta abordagem e notação diferenciada;

- Verificar a adição desta abordagem em paralelo à usual dos logaritmos, mesmo que como uma nova maneira de encarar os mesmos, para analisar as escolhas dos alunos quanto à representação que cada um acredita ser mais adequada para se tratar dos expoentes e realizar operações;

- Comparar e discutir ambas as maneiras de se escrever este objeto matemático, a usual e a proposta neste texto, com outros professores e verificar a aceitação destes para com uma nova notação.

Todas estas atividades e experiências exigiriam desde análises quantitativas e qualitativas que aumentariam em muito a extensão desde trabalho, que por sua vez tem como objetivo principal a proposição da inclusão de novos fatores gramaticais e linguísticos na elaboração de notação matemática e possui um cunho mais explicativo. Desta maneira foram realizadas as chamadas entrevistas focais, definidas por Yin (2001, p. 133) como sendo relativamente curtas, espontâneas e em tom de conversa informal, mesmo que o pesquisador esteja se baseando num conjunto de perguntas pré-formuladas, com três educadores que manteremos anônimos e serão aqui representados pelas letras A, B e C. Estas entrevistas foram realizadas como um piloto para o quarto item das atividades que acreditamos serem significativas para esta análise.

\subsubsection{Entrevistas}

Estas entrevistas foram realizadas como uma maneira de verificar o posicionamento de alguns professores que atuam atualmente em suas respectivas áreas e escolas quanto a uma proposição de nova notação para os logaritmos, incluindo uma nova maneira de ler, como e 
quando abordar e compreender este objeto matemático, tal como uma amostra para a realização do último tópico das atividades que temos interesse de aplicar num possível futuro trabalho. Da mesma maneira, tanto em questão de gestão de tempo e viabilidade, não realizaremos um estudo mais aprofundado baseado nos outros três tópicos, por necessitarem de uma maior carga de tempo e análise, que os fariam estender demasiadamente este trabalho. Acreditamos também que o principal foco de estudo neste momento inicial é o das concepções dos profissionais de ensino, pois estes são os principais mediadores que poderão utilizar desta notação de maneira didática.

Quando nos referimos às concepções dos profissionais de ensino, estamos nos referindo, nas palavras de Garnica e de Ponte:

\begin{abstract}
Vamos considerar como "concepções" os "algos" (crenças, percepções, juízos, experiências prévias etc.) a partir dos quais nos julgamos aptos a agir. Concepções são, portanto, suportes para a ação. Mantendo-se relativamente estáveis, as conce opões criam em nós alguns hábitos, algumas formas de intervenção que julgamos seguras. Essa vinculação entre concepção e ação não é nova nem pode ser creditada a uma única teoria. Vários teóricos trataram do tema da ação, das principais práticas humanas e de seus fundamentos. Segundo Romulo Campos Lins (1999), a associação entre produção de conhecimento e ação tem uma longa tradição, que passa, por exemplo, por Charles Sanders Peirce, Gaston Bachelard e Gerard Vergnaud (GARNICA), 2008, p. 499)
\end{abstract}

O interesse pelo estudo das concepções de professores, tal como, aliás, pelo estudo das concepções de outros profissionais e de outros grupos humanos, baseia-se no pressuposto de que existe um substracto conceptual que joga um papel determinante no pensamento e na acção. Este substrato é de uma natureza diferente dos conceitos específicos - não diz respeito a objectos ou acções bem determinadas, mas antes constitui uma forma de os organizar, de ver o mundo, de pensar. Não se reduz aos aspectos mais imediatamente observáveis do comportamento e não se revela com facilidade - nem aos outros nem a nós mesmos.

As concepções tem uma natureza essencialmente cognitiva. Actuam como uma espécie de filtro. Por um lado, são indispensáveis, pois estruturam o sentido que damos às coisas. Por outro lado, actuam como elemento bloqueador em relação a novas realidades ou a certos problemas, limitando as nossas possibilidades de actuação e compreensão.

As concepções formam-se num processo simultaneamente individual (como resultado da elaboração sobre a nossa experiência) e social (como resultado do confronto das nossas elaborações com as dos outros). Assim, as nossas concepções sobre Matemática são influenciadas pelas experiências que nos habituamos a reconhecer como tal e também pelas representações sociais dominantes (PONTE, 1992, p. 1)

Estas concepções portanto são um crivo pelos quais novas ideias devem passar para serem aceitas ou não por um indivíduo, estruturam o sentido que damos às coisas e estão vinculadas com as ações que virão. Não são reveladas com facilidade e se formam 
individualmente para então serem refinadas em atritos ou concordâncias com uma concepção de outros indivíduos. Podemos ver estas concepções em parte como os pontos de vista diferentes que enxergamos e representamos individualmente um objeto maior, no nosso caso, os logaritmos como expoentes e uma maneira alternativa de representá-los.

Ainda nas ideias de Ponte e Garnica, professores que, portanto, através de suas crenças, percepções, juízos e experiências prévias, julguem inválidas as ideias apresentadas neste trabalho estarão menos aptos a aceitar uma possível mudança de notação, e como esta mudança baseia-se na Língua Materna desses professores e seus alunos, tentando ser mais compreensiva e aplicável que a atual, caso ela falhasse já inicialmente em ser ao menos considerada válida como proposta de intervenção, teríamos encalhado antes mesmo de partir numa viagem inaugural.

Optamos por não transcrever os registros de audio completos de cada uma das três entrevistas, que duraram cerca de 70 minutos cada, por compreender que isto seria desnecessário aos propósitos desta dissertação. O foco de cada entrevista era principalmente uma exposição resumida das ideias deste trabalho para os três profissionais da educação em busca das concepções que seriam formadas por cada um deles em relação a este assunto. As entrevistas foram semiestruturadas conforme seu decorrer, foi alterado o fluxo da conversa, incluímos ou omitimos algumas perguntas e buscamos sempre manter o ambiente informal de modo que as entrevistas pudessem transcorrer de maneira fluída e autêntica. As entrevistas ocorreram em setembro de 2018, foram realizadas individualmente e seus objetivos eram colher as concepções de cada professor, validar algumas de nossas interpretações e inferências, mesmo que pontualmente, e analisar a aceitação dos entrevistados para com o tema deste trabalho e a maneira como foi encadeado.

O entrevistado A é um professor de Matemática jovem que iniciou sua vida docente há poucos anos, possui uma visão de recém-graduado na educação e trás ideias de sua formação em suas palavras.

Relatou não estar satisfeito com a abordagem atual dos logaritmos, diz que seus alunos costumam ter dúvidas quanto a este objeto matemático e nunca havia pensado em alterar o modo como, particularmente, tenta expor e construir este conhecimento em sala de aula.

Observou que já tenta mostrar para os alunos que os logaritmos podem ser vistos como expoentes, mas não com estas palavras específicas, e que alcança resultados mais favoráveis quando ancora mais os logaritmos à exponencial do que como um conhecimento paralelo. 
Mostrou-se preocupado com a troca de notação, por poder criar um nicho de usuários que fosse incapazes de se comunicar com o restante da população mas que fora este receio de perda de generalidade da linguagem matemática, está confortável em buscar uma nova forma de representação dos logaritmos, por serem um conteúdo que é considerado "difícil de ser compreendido" e que faria sentido possuir sua forma alterada, desde que não se maculasse o significado do objeto.

Apontou que muitas vezes, em seu exemplo na generalização de um polinômio, alguns conceitos matemáticos são mais facilmente representados pela fala ou pela escrita por extenso em Língua Materna do que na sua forma matemática padrão e portanto considerar a Língua Materna em suas aulas como mais uma representação dos conteúdos matemáticos pode ajudar na compreensão de outros objetos além dos logaritmos e polinômios. Também disse que passaria a prestar mais atenção nos momentos em que usa uma linguagem mais própria da Língua Materna, pois acredita que seus alunos costumam reagir bem a este incentivo. Relatou por fim que gostaria de passar uma imagem da Matemática que fosse menos arcaica, escrita em pedra, imutável e completa, como nos slogans analisados por Nílson José Machado, e sim uma imagem que fosse mais representativa da Matemática moderna, nas quais estes adjetivos não se aplicam.

O entrevistado B é um professor de Língua Portuguesa com muita experiência em docência na escola básica e no ensino médio. Seu lado filósofo e poeta foi bastante presente durante a entrevista e nos propiciou com pontos de vista e ideias diferentes das apresentadas pelos outros dois entrevistados que são professores de Matemática. Por causa disto, esta entrevista foi particularmente rica e transcorreu de maneira mais voltada à parte gramatical da representação de um objeto do que ao ensino dos logaritmos em sala de aula.

Comentou que a gramática determinística, num plano da análise linguística, afirma que a língua é o método com o qual cada indivíduo compreende o mundo, deu o exemplo de que os gregos não possuíam uma palavra para a cor azul, porque para eles esta cor não existia, era considerada um tom de outra cor. Num ponto de vista linguístico, isto é um deficit no conhecimento pois eles não eram capazes de expressar aquela cor em particular. Conforme o tempo passou e eles tiveram contato com outras civilizações e outras línguas, tornou-se necessário distinguir esta cor das outras, e a partir de então ela recebeu um nome e passou a ser parte do conjunto de objetos da Língua grega. Quando você tem contato com uma outra Língua, você aprende a ver o conhecimento de uma outra maneira, seguiu então dizendo que 
oe esquimós possuem mais de uma dezena de palavras para se referir a neve, dependendo das propriedades que cada neve apresenta. Esta diferenciação se dá devido à necessidade deste povo de se referir a um tipo de neve com consistência ou capacidades específicas para sua sobrevivência.

Comentou da estrutura ortodoxa da Língua Materna, a SVC (Sujeito - verbo complemento) que nada mais é do que uma outra representação da estrutura SVO proposta na Gramática Gerativa. Mostrou que na Língua Materna, é possível que sentença não tenha um complemento, como no exemplo

\section{Ele morreu ontem.}

Onde "ele" é sujeito da ação que é aplicada sobre si mesmo (morrer) e ontem representa tempo, mas não é uma partícula fundamental para que essa frase possuía significado. Muitas vezes um poeta ou escritor não segue a estrutura ortodoxa da Língua Materna, pois a Língua possui a flexibilidade e potencial de uma multiplicidade de significações, uma riqueza de linguagem.

Apontou que em sua vida de estudante, os logaritmos eram uma incógnita por não ser evidente seu papel e eram difíceis de serem "alcançados” por estarem num "plano" superior, referia-se ao papel dos expoentes e como eles possuem uma manipulação diferente das outras operações como soma e multiplicação, além de graficamente estarem numa superposição com relação a linha. Acredita que a notação matemática que tenha o potencial de ser simples o deveria fazer e ficou confiante com a representação proposta de um logaritmo, palavra que não possuía um significado além do objeto matemático em questão, por um expoente, que é um termo recorrente tanto em utilização quanto em presença nas aulas de matemática. Disse que como estudante, a quebra da necessidade de ter que converter logaritmos para exponenciais para conseguir manipulá-los seria um diferencial importante para um maior sucesso escolar.

Foi este entrevistado quem sugeriu o poema utilizado na epígrafe deste trabalho, poema este que passa a ideia de que não importa o modo como se fala, se o objetivo verdadeiro é alcançado.

$\mathrm{O}$ entrevistado $\mathrm{C}$ é um professor doutor em Matemática que leciona há muito tempo e possui experiências vastas na área além de um amor muito grande pela sua profissão. Dos três entrevistados foi o que mais apresentou preocupação e sugestões para o modo como escrevi e 
apresentei ideias, pontos importantes na vida acadêmica. Sua própria formação promoveu um encontro entre estudos matemáticos e de Língua Materna, sua maneira de encarar as ideias e perguntas da entrevista se mostrou muito mesclada de conceitos sintáticos, metafóricos e matemáticos.

Apontou que para Romulo Campos Lins, a crença pode ser entendida como um par ordenado (crença, justificativa), pois sempre que um individuo apresenta uma crença, em seguida ele justifica essa crença de alguma maneira. Neste processo de justificação ocorre a produção de saber, mas sua vez, na escrita matemática, muitas vezes não temos o costume de fazer esta justificativa. Comentou que uma declaração numa aula de lógica que utilize "a mesa é redonda" inicialmente se aparenta com uma declaração como "xis é igual a cinco", mas é mais fácil justificar que uma mesa retangular não é redonda do que justificar que "sete mais cinco é igual a vinte", devido à justificativa na Matemática ser tomada normalmente como algo implícito.

Comentou que para alunos cegos, um importante instrumento de aprendizagem é o LaTeX, que possui uma escrita linear, pois expoentes e índices geral confusão na "visualização" destes alunos, mas que há resultados muito mais satisfatórios usando uma linguagem mais linearizada que evita estas mudanças de direção na leitura.

Comentou que a Linguística Cognitiva defende que a maior parte do raciocínio humano é metafórico, trabalhamos com inferências de objetos mais simples para entendermos objetos mais abstratos. Quando dizemos “Tempo é dinheiro" estamos relacionando ambos os objetos. Para entender o tempo, usamos sentenças e ideias normalmente relacionadas com o dinheiro, que é um objeto menos abstrato. É daí que temos expressões como "isto vai me custar tempo", o que não é literalmente o que ocorre, não é possível utilizar o tempo como um pagamento, mas tratamos como se fosse. Existem metáforas entre a Matemática e a Língua Materna assim como existem metáforas dentro da Matemática, por exemplo entre a Geometria e a Álgebra, um exemplo disso é o ciclo trigonométrico, que envolve uma grande quantidade de pensamentos e objetos matemáticos, com suas respectivas propriedades, aglomerados num único lugar, unindo a reta real, ângulos, trigonometria e até mesmo o conceito de infinito potencial.

Estas entrevistas foram, cada uma de sua maneira, muito significativas para o andamento final deste trabalho, cada um dos professores, mesmo tendo ideias, posições e formações diferentes, passaram a crença de que o ensino dos logaritmos seria mais 
significativo a partir de uma mudança de sua escrita, pois a representação atual não aparenta comportar as ideias mais importantes dos logaritmos na modernidade. Esta mesma notação que já foi um avanço na representação dos logaritmos pode ser revista e reformulada, pois há maneiras de torná-la mais significativa como representação semiótica do objeto em questão. 


\section{CONCLUSÃO}

Os logaritmos, como conhecimento, sofreram transformações ao longo dos séculos desde sua definição e motivação iniciais. Estas transformações foram internas, em um maior agregamento de significados diferentes, e externas, em questão de seus usos e aplicações práticas. Usos estes que cada vez mais se mostram abrangentes em diferentes áreas do conhecimento, a todo momento que se vale de um crescimento (ou decrescimento) proporcional ao valor atual em questão, ou seja, uma exponencial, também podemos pensar na maneira de alcançar este valor respectivo, ou seja, na inversão deste processo. Estamos falando então do expoente que faz com que uma base se torne o logaritmando.

Representar o logaritmo como expoente é uma diferente forma de representação do mesmo objeto matemático, e tal como toda representação semiótica tanto representa parte das características do objeto quanto deixa de representar outras. A análise feita neste trabalho mostra que a parte representada é significativa por se aproximar da maneira de organizar o raciocínio utilizada por falantes da Língua Portuguesa e possibilita uma aprendizagem diferenciada com relação à usual, tanto por abrir maneiras de se fazer referência ao logaritmo quanto em maneira de representá-lo: o expoente c que leva uma base a no exponenciando b.

A mudança na interpretação do logaritmo não altera o significado deste objeto, somente os signos que usamos para representá-lo. Esta alteração de notação não é algo completamente distópico com relação à linguagem matemática usada no mundo, várias culturas possuem maneiras diferentes de se referir a um mesmo objeto: sejam os americanos com os signos sin, tan, $\log _{e}$ em contrapartida com os nossos de sen, $t g, \ln$ em que diferentes línguas utilizam-se de signos diferentes, ou a Notação Polonesa Inversa desenvolvida pelo filósofo e cientista computacional australiano Charles Hamblin, esta notação foi considerada "muito difícil" num primeiro momento mas por maximizar a velocidade de operações, minimizar os erros ao se utilizar de um sistema de input de valores seguido das operações, e reduzir o número de passos necessários para realizar uma conta, diminuindo ainda mais o trabalho do computador, esta notação foi adotada por calculadoras da marca HP (WHITNEY, et al. 1972). A Notação Polonesa Inversa possui uma sintaxe totalmente diferente da usual, o que inicialmente causou certa aversão e não foi considerada uma saber a ser ensinado mas mesmo perante opiniões muitas vezes negativas encontrou uma aplicação devido às suas propriedades e potencial. 
Os saberes a ensinar possuem um trajeto longo que se inicia numa motivação da noosfera em desejar que este saber seja parte do conhecimento geral da população. Para tanto, um conhecimento científico é então transformado para ser ensinado, este processo leva em conta fatores sociais, políticos e didáticos, entre outros, e pode levar certo tempo para efetivamente garantir a presença deste conhecimento nos livros didáticos e salas de aula. A noosfera, segundo Chevallard, não é uma entidade singular mas sim o conjunto de professores, políticos, líderes empresariais, cientistas, autores de livros didáticos e outros que também influenciam a seleção de conteúdos que compõem o saber escolar.

A partir do momento que um saber é ensinado, o aluno então busca representar este conhecimento como um saber próprio e significativo para si mesmo. Esta representação deve possuir um certo nível de aceitação em sua reprodução, que é exigido pelo professor para normalizar as produções de seus alunos e garantir que estes comuniquem e sejam compreendidos de maneira adequada. As regras de conformidade e a sintaxe fazem parte destas exigências e normalizações. Um texto, seja ele matemático ou não, deve ser coeso e coerente para que se evitem falsas interpretações, para tanto acreditamos ser de suma importância que a notação utilizada seja significativa para este aluno.

Além de sua posição em meio a teia de conhecimentos matemáticos, a significância de uma representação também deve levar em conta a língua falada pelo usuário alvo, pois é esta língua a principal base para o raciocínio, e portanto parte imprescindível da cognição. Em particular, nossa Língua Materna possui uma ordem ortodoxa SVO, em que a leitura se dá da esquerda para a direita, de maneira linear e rica em atribuição de características a sujeitos. Ter em mente estas características nos proporciona possíveis maneiras de reformular uma notação para que esta seja mais significativa, no caso dos logaritmos, que podemos considerar como sendo expoentes, acreditamos que possa ser dada da forma:

$$
x \text { po } a \rightarrow b=c
$$

Por reunir a ideia da linearidade, leitura sequencial direta da esquerda para a direita, atribuição de uma propriedade chave a um sujeito (ser o número que leva a em b) e não alterar o significado do logaritmo, mas sim a maneira como o representamos. Esta nova representação portanto possui propriedades não tão presentes de maneira explícita pela representação usual dos logaritmos, por ser uma representação semiótica diferente, e ao mínimo pode ser usada como complementariedade para o ensino de logaritmos atual por proporcionar um novo ponto de vista, e portanto uma nova maneira de transitar entre 
representações semióticas, a semiósis, que como afirma Duval é condição necessária para que ocorra a apreensão do conhecimento como saber, a noésis.

Devido à maneira como foi concebido, de ferramenta facilitadora de cálculo, devemos tomar o cuidado para que os logaritmos não se reduzam a tal condição. São um poderoso objeto matemático mas quando a única maneira que um aluno encontra de operar este objeto é através de suas ligações com a exponencial, isto pode ser o sinal de uma má formação do saber deste estudante. Devemos sempre buscar a transição entre representações semióticas tanto quanto a formação de uma representação semiótica em si.

Ao discutir com outros profissionais docentes, num primeiro momento a aceitação desta nova maneira de se representar o objeto matemático dos logaritmos foi unânime: as vantagens que apresenta por ser uma notação mais simples com signos mais próximos do cotidiano do aluno são, ao menos para os professores em questão, suficientes para justificar uma alteração na notação usual dos logaritmos, que por sua vez não foi reformulada desde sua proposição por Euler, quase três séculos atrás. Não iremos, apesar disso, realizar as aplicações pertinentes por se crer que fugiria do escopo deste trabalho, de cunho principalmente explicativo, ao visto de que estas aplicações seriam extensas, ao longo de anos, e acreditarmos que uma atividade ou duas não geraria dados suficientes para validar esta proposição.

Uma nova notação para os logaritmos se valeria como maneira auxiliar de representar este conhecimento, mas a noosfera exige a notação usual. Um aluno que porventura dominasse ambas ainda teria de realizar traduções para a forma atual de representação para expor seus conhecimentos numa atividade avaliativa como um vestibular, por estas serem as regras de conformidade exigidas do mesmo. Uma notação auxiliar que ainda dependesse da atual iria contra os pontos propostos neste trabalho.

Observamos que a Língua Materna influencia o modo de se organizar as sentenças, e por sua vez, o raciocínio de seus falantes. Esta influência permeia todos os conhecimentos, incluindo a Matemática, e é significativo considerá-la no processo de ensino e aprendizagem, por ser também uma nova maneira de enxergar um mesmo ponto de vista: podemos representar um polinômio como sendo por sua forma arbitrária em notação matemática, em notação escrita em português ou até mesmo pela fala. Todas estas representações diferentes podem auxiliar o aluno a visualizar melhor o objeto matemático em questão e, com certeza, se utilizar desta multiplicidade de representações não somente é algo indispensável para a aprendizagem quanto é uma prática possivelmente comum a muitos professores de 
matemática, mas de uma forma sutil que passa desapercebida em muitas vezes.

Analisar a maneira como os logaritmos evoluiram como conhecimento através do tempo mostra-se uma maneira significativa de compreender o valor atual deste objeto matemático, não podemos justificar sua presença em sala de aula ao se utilizar de argumentos flácidos de que ele era um facilitador de operações, haja vista que esta utilização praticamente deixou o escopo dos significados dos logaritmos, sendo uma aplicação muito mais crucial há algumas centenas de anos atrás do que é hoje. Apesar deste significado ter se reduzido, uma miríade de outros foi anexada aos logaritmos que atuam de maneira fulcral para diversas áreas do conhecimento humano.

A Matemática não é uma área da ciência unicamente exata e precisa ao mesmo tempo que a Língua Materna não é totalmente alheia à determinismos e mecanização. Todas as ciências possuem aspectos qualitativos e quantitativos, exatos e humanos, de generalização e de redução a casos. Ainda assim, ao menos na Escola Básica, a impressão que perdura é a do slogan de que a matemática é exata e "dois mais dois serão sempre quatro", um argumento inválido ao se considerar o conjunto $\mathbb{Z}_{3}$.

Como era de se esperar, a investigação realizada abriu novas questões a serem consideradas, mas dentro dos limites e alcance de um trabalho de mestrado, acreditamos termos alcançado nossos objetivos iniciais e esperamos ter aberto possibilidades para outros trabalhos futuros, tanto na notação dos logaritmos quanto na de outros objetos matemáticos.

A maturidade e aprofundamento teórico que a pesquisa nos conduziu foi uma experiência única de desenvolvimento e formação de caráter pedagógico, abriu novos horizontes de pensamento e permitiu um contato ímpar com ideias didáticas que refletem e se refinam a cada novo momento de ensino.

Por último, esperamos que este trabalho seja significativo para todos e qualquer leitor interessado. 


\section{REFERÊNCIAS BIBLIOGRÁFICAS}

BRASIL, Base Nacional Comum Curricular (BNCC), Terceira versão revista. Brasília MEC/CONSED/UNDIME, 2017. Disponível em < http://basenacionalcomum.mec.gov.br/wpcontent/uploads/2018/02/bncc-20dez-site.pdf $>$, acesso em setembro de 2018.

CAMPOS, H, de (Org.). Ideograma. São Paulo: Editora Cultrix/Edusp, 1977.

CAPRA, F. O Tao da física. São Paulo: Editora Cultrix, 16 a ed. 1995.

CHEVALLARD, Y. La Transposition Didactique: du savoir savant au savoir enseigé. Grenoble, La Pensée Sauvage, 1991.

CHOMSKY, Noan. Aspects of the theory of syntax. MIT Press, 1965. . The Minimalis Program. MIT Press, 1995.

CRYSTAL, David. The Cambridge Encyclopedia of Language. Cambridge University Press, 2010.

DEVITO, André, FREITAS, Araone Koaerece de, PEREIRA, Kênia Cristina. Geometrias NãoEuclidianas. Disponível em

$<$ http://www.ime.unicamp.br/ eliane/ma241/trabalhos/nao_euclidiana $>$. Acesso em abril de 2018.

DUARTE, Vânia Maria do Nascimento. Articulações da língua, Brasil Escola. Disponível em $<$ https://brasilescola.uol.com.br/gramatica/articulacoes-lingua.htm> . Acesso em agosto de 2018 .

DUBOIS, Jean. Dicionário de Linguística. São Paulo: Cultrix. 2a ed. 2014.

DUVAL, Raymond. Semiósis e pensamento humano: Registros semióticos e aprendizagens intelectuais. $1^{\mathrm{a}}$ ed. São Paulo: Editora Livraria da Física, 2009.

DUVAL, Raymond; FREITAS, José Luiz Magalhães; REZENDE, Veridiana. Entrevista: Raymond Duval e a Teoria dos Registros de Representação Semiótica. Revista Paranaense de Educação Matemática, v. 2, p. 13-34, 2013.

ELLSWORTH, William L. The Richter Scale $M_{L}$, from The San Andreas Fault System. Califórnia (Professional Paper 1515), USGS, c. 6, p. 177 , 2008.

EVES, Howard. Introdução à História da Matemática. Campinas, SP: Editora Unicamp. 2004. 
FEYNMAN, Richard. The Feynman Lectures on Physics: Volume I, S.I. s.n. 1970.

FERREIRO, E. Reflexões sobre alfabetização. São Paulo: Editora Cortez, 1986.

GARNICA, A. V. M. Um ensaio sobre as concepções de professoresde matemática: possibilidades metodológicas e um exercício de pesquisa. Educação e pesquisa, São Paulo, v. 34, n. 3, p. 495-510, 2008.

HALSTED, George Bruce, Biography: [Nicolai Ivanovich] Lobachevsky, The American

Mathematical Monthly, Volume 2, 1895.

IEEE Standard 100, The Authoritative Dictionary of IEEE Standards Terms, $7^{\mathrm{a}}$ ed, IEEE, Nova Iorque, p. 288, 2000.

LORIA, Gino. Guida allo Studio della Storia delle Matematiche. $2^{\mathrm{a}}$ ed. Milano, Ulrico Hoepli, p.15, 1946

MACHADO, Nílson José, CUNHA, Marisa Ortegoza da. Lógica e linguagem cotidiana: verdade, coerência, comunicação, argumentação. $2^{\mathrm{a}}$ ed. Editora Autêntica, Belo Horizonte, 2008.

MACHADO, Nílson José. Matemática e língua materna: análise de uma impregnação mútua. $6^{\mathrm{a}}$ ed. São Paulo: Cortez, 2011.

Sementes 114 \# ÉTICA NO MEIO ACADÊMICO: Linguagem

adequada para respeitar as diferenças. Disponível em:

$<$ http://www.nilsonjosemachado.net/sementes-114-etica-no-meio-academico-linguagem-adequadapara-respeitar-as-diferencas/>. Acesso em abril de 2018.

MACHADO, S. D. A. et al. Educação Matemática: uma (nova) introdução. São Paulo: EDUC, 2010.

MAOR, Eli. e:The story of a Number, Princeton, Nova Jersey: Princeton University Press, 1994.

MARTINET, André. Elementos de linguística geral, Brasil: Martins Fontes Editora Ltda, 8 aed. 1978.

MENEZES, Luiz. Matemática, Linguagem e Comunicação. Disponível em $<$ http://www.ipv.pt/millenium/20_ect3.htm>. Acesso em março de 2018. 
MORETTI, M. T.; THIEL, A. A. O ensino de matemática hermético: um olhar crítico a partir dos registros de representação semiótica. Práxis Educativa UEPG, v. 7, 2012.

MOTTA, Alan. SVO, 2015 disponível em

$<$ https://oprogramalinguisticalista.wordpress.com/tag/svo/>. Acesso em julho de 2018.

PONTE, J. P. Concepções dos professores de matemática e processos de formação. Departamento de Educação - Faculdade de Ciências, Lisboa, 1992. Disponível em $<$ http://www.educ.fc.ul.pt/docentes/jponte/docs-pt/92-Ponte\%28Ericeira\%29.pdf $>$, acesso em setembro de 2018;

RODIN, Audrey, Did Lobachevsky Have A Model Of His "imaginary Geometry"? , S.I. s.n. 2010.

SANTOS, J. R. V., LINS, R. C. Movimentos de Teorizações em Educação Matemática. Bolema:

Boletim de Educação Matemática. Vol. 30, n. 55. Rio Claro, 2016

SOARES, Flávia do Santos et al, Ensino de matemática no século XX - da Reforma Francisco Campos à Matemática Moderna, Horizontes, Bragança Paulista, v. 22, n 1, p. 7-15, 2004.

WHITNEY, T. M. RODE, F. TUNG, C. C. The 'Powerful Pocketful': an Electronic Calculator Challanges the Slide Rude. Hewlett-Packard Journal, vol. Junho, Artigo 1, 1972.

YIN, R. K. Estudo de caso: planejamento e método, Trad. Daniel Grassi, 2a ed. Porto Alegre: Bookman, 2001. 